\title{
22. COMPOSITIONAL TRENDS IN NATURAL BASALTIC GLASSES FROM DEEP SEA DRILLING PROJECT HOLES 417D AND 418A ${ }^{1}$
}

\author{
Gary R. Byerly, Department of Geology, Louisiana State University, Baton Rouge, Louisiana \\ and \\ John M. Sinton, Hawaii Institute of Geophysics, University of Hawaii, Honolulu, Hawaii
}

\begin{abstract}
Fresh glassy selvages are preserved throughout many basalt intervals in Holes 417D and 418A. Eruptive units identified on the basis of major element analyses of these glasses correlate quite well with those defined on the basis of lithology and magnetic inclinations. Much of the chemical variation found in the glasses can be related to shallow-level fractional crystallization though multiple parental liquids are required. Basaltic glasses from these two holes fall within the range of glass compositions found for modern ocean spreading centers.
\end{abstract}

\section{INTRODUCTION}

In spite of the common occurrence of fresh glass in old oceanic crust, it was surprising to find that in Holes 417D and 418A glass was not only present but was preserved on many pillow margins throughout most intervals. Preservation of this metastable material must have important implications for temperature distribution, stress relationships, and particularly fluid movements in the oceanic crust as it moves away from the mid-ocean spreading center. The shipboard scientists from Leg 51 contrasted the highly altered condition of the rocks from Hole 417A to the much fresher rocks in Hole 417D and suggested that prolonged exposure to sea water was responsible for the intense alteration. No fresh glass was found in Hole 417A.

In this paper, we report the major-element chemistry of the basaltic glasses recovered from these two holes. The glass analyses reported in this study allow the definition of a chemical stratigraphy, which, combined with the lithologic and magnetic stratigraphy, helps define single eruptive units. Chemical averages for continuous sequences within each hole are used to test the hypothesis that two or more chemical types are related by low-pressure fractional crystallization.

Glass analyses are compared to the preliminary shipboard whole-rock analyses. The comparison clearly demonstrates the importance of plagioclase accumulation in these rocks. Analyses of glass inclusions in plagioclase are used to determine the possible evolution of the basaltic liquids parental to the basalts recovered in Holes 417D and 418A. Finally, the chemical variation found in these two holes is compared to the large set of glass analyses reported in Melson et al. (1976) for basalts from modern spreading centers.

\section{SAMPLING AND ANALYSIS}

Basalts in Holes 417D and 418A occurred as pillowed flows, massive flows (sills?), breccias, and dikes. Fresh

${ }^{1}$ HIG Contribution No. 998. glass occurred most commonly in the selvages of the pillowed flows. Brecciated zones within pillowed flows often showed complete alteration of glassy selvages to smectite, carbonate, and zeolite. The glassy selvages of massive flows and dikes were often entirely altered; this may reflect prolonged high temperatures at these contacts and increased susceptibility of the glassy selvages to alteration.

An attempt was made to sample glasses near the top and bottom of each lithologic unit and at intervals of five meters or less within each unit. In many cases, sampling was more dense than this. Between 510 and 603 meters sub-bottom in Hole 418A, we obtained 41 samples within a single lithologic unit. Sampled glasses for which fresh material was found and analyzed are presented in Tables 1A (417D) and 1B (418A).

Glass analyses were done at the Smithsonian Institution on a 9- spectrometer ARL-SEMQ electron microprobe. The operating conditions, correction procedures, and estimated precision are summarized in Byerly et al. (1977). New interlaboratory comparisons of the precision and accuracy of glass analyses by electron microprobe are made by Jarosewich et al. (in press).

\section{A CHEMICAL STRATIGRAPHY}

The analyses of Tables 1A (417D) and 1B (418A) are arranged in stratigraphic order from the top of each hole. These data are also plotted against depth in Figures 1a, b, c (417D) and 2a, b, c (418A). Two points emerge from a reconnaissance of the relationship of these data to stratigraphic position. First, discontinuities occur in many places, suggestive of separate eruptive events. Second, compositions occurring between these discontinuities tend to be very uniform. Such horizons probably represent single eruptive events. Other evidence exists to support this interpretation. Generally little or no sediment is found within these horizons. More importantly, tightly grouped paleomagnetic inclinations within these units suggest formation within short intervals of time. Units of similar 
TABLE 1A

Chemistry Versus Depth, DSDP Hole 417D

\begin{tabular}{|c|c|c|c|c|c|c|c|c|c|c|c|c|c|}
\hline $\begin{array}{c}\text { Sample } \\
\text { (Interval in } \mathrm{cm} \text { ) }\end{array}$ & $\begin{array}{c}\text { Chemical } \\
\text { Type }\end{array}$ & $\mathrm{SiO}_{2}$ & $\mathrm{Al}_{2} \mathrm{O}_{3}$ & $\mathrm{FeOT}$ & $\mathrm{MgO}$ & $\mathrm{CaO}$ & $\mathrm{Na}_{2} \mathrm{O}$ & $\mathrm{K}_{2} \mathrm{O}$ & $\mathrm{TiO}_{2}$ & $\mathrm{P}_{2} \mathrm{O}_{5}$ & $\begin{array}{l}\text { Sub-Bottom } \\
\text { Depth (m) }\end{array}$ & VGM & Total \\
\hline $22-1,73$ & A & 51.05 & 14.29 & 11.52 & 7.21 & 11.90 & 2.33 & 0.08 & 1.60 & 0.14 & 344.73 & 2899 & 100.12 \\
\hline $22-3,27$ & A & 50.33 & 14.48 & 11.36 & 7.23 & 11.71 & 2.32 & 0.10 & 1.57 & 0.13 & 347.27 & 2900 & 99.23 \\
\hline $22-4,113$ & A & 50.28 & 14.34 & 10.99 & 7.10 & 11.75 & 2.32 & 0.09 & 1.58 & 0.16 & 349.63 & 2843 & 98.61 \\
\hline $22-5,17$ & A & 50.14 & 14.67 & 11.39 & 7.27 & 11.86 & 2.30 & 0.09 & 1.57 & 0.15 & 350.17 & 2844 & 99.44 \\
\hline $22-7,28$ & A & 50.21 & 14.34 & 11.51 & 7.26 & 11.70 & 2.33 & 0.08 & 1.63 & 0.15 & 353.28 & 2845 & 99.21 \\
\hline $26-2,89$ & A & 50.10 & 14.28 & 11.47 & 7.05 & 11.50 & 2.39 & 0.15 & 1.68 & 0.14 & 359.84 & 2846 & 98.76 \\
\hline $26-3,40$ & A & 50.53 & 14.43 & 11.45 & 7.11 & 11.63 & 2.35 & 0.09 & 1.61 & 0.15 & 360.83 & 2901 & 99.35 \\
\hline $26-7,3$ & A & 50.61 & 14.57 & 10.88 & 7.07 & 11.75 & 2.34 & 0.10 & 1.55 & 0.13 & 366.35 & 2902 & 99.00 \\
\hline $27-1,73$ & A & 50.59 & 14.51 & 11.25 & 7.41 & 11.71 & 2.25 & 0.11 & 1.59 & 0.14 & 367.29 & 2903 & 99.56 \\
\hline $27-2,5$ & A & 50.71 & 14.73 & 10.86 & 7.26 & 11.81 & 2.36 & 0.11 & 1.54 & 0.13 & 368.07 & 2904 & 99.51 \\
\hline $27-4,131$ & B & 50.75 & 14.70 & 11.24 & 7.30 & 11.81 & 2.29 & 0.09 & 1.56 & 0.15 & 370.69 & 2847 & 99.89 \\
\hline $27-7,13$ & B & 50.57 & 14.63 & 11.16 & 7.44 & 11.78 & 2.28 & 0.09 & 1.54 & 0.14 & 375.27 & 2848 & 99.63 \\
\hline $28-2,15$ & B & 50.96 & 14.54 & 11.23 & 7.56 & 11.76 & 2.23 & 0.10 & 1.51 & 0.13 & 377.20 & 2905 & 100.02 \\
\hline $28-3,3$ & B & 50.86 & 14.49 & 11.32 & 7.37 & 11.92 & 2.25 & 0.08 & 1.48 & 0.13 & 378.36 & 2849 & 99.90 \\
\hline $28-6,100$ & B & 50.91 & 14.75 & 11.05 & 7.47 & 11.99 & 2.28 & 0.10 & 1.47 & 0.14 & 383.44 & 2906 & 100.16 \\
\hline $28-X$ & B & 50.26 & 14.84 & 11.13 & 7.54 & 11.87 & 2.31 & 0.07 & 1.53 & 0.14 & 384.80 & 2867 & 99.69 \\
\hline $28-X$ & B & 50.81 & 14.88 & 11.13 & 7.70 & 11.99 & 2.34 & 0.10 & 1.56 & 0.13 & 384.80 & 2868 & 100.64 \\
\hline $29-1,110$ & B & 50.48 & 14.84 & 11.17 & 7.56 & 11.91 & 2.27 & 0.09 & 1.48 & 0.12 & 385.80 & 2907 & 99.92 \\
\hline $29-4,33$ & B & 50.88 & 14.52 & 11.21 & 7.62 & 11.92 & 2.26 & 0.08 & 1.51 & 0.13 & 389.20 & 2850 & 100.13 \\
\hline $29-4,129$ & B & 51.01 & 14.56 & 11.36 & 7.67 & 12.01 & 2.24 & 0.08 & 1.47 & 0.12 & 390.07 & 2851 & 100.52 \\
\hline $29-5,98$ & B & 50.72 & 14.50 & 11.17 & 7.71 & 11.84 & 2.24 & 0.09 & 1.47 & 0.14 & 391.15 & 2852 & 99.88 \\
\hline $30-5,106$ & B & 50.74 & 14.59 & 11.48 & 7.44 & 11.85 & 2.22 & 0.09 & 1.51 & 0.11 & 399.48 & 2853 & 100.03 \\
\hline $30-6,20$ & B & 50.77 & 14.56 & 11.43 & 7.69 & 11.90 & 2.26 & 0.08 & 1.52 & 0.12 & 399.99 & 2908 & 100.33 \\
\hline $30-6,35$ & B & 50.57 & 14.48 & 11.35 & 7.36 & 11.83 & 2.28 & 0.08 & 1.61 & 0.12 & 400.11 & 2854 & 99.68 \\
\hline $31-4,15$ & B & 51.17 & 14.92 & 11.09 & 7.30 & 11.92 & 2.39 & 0.12 & 1.52 & 0.16 & 407.65 & 2909 & 100.59 \\
\hline $32-1,51$ & B & 50.40 & 14.47 & 11.11 & 7.21 & 11.89 & 2.37 & 0.11 & 1.56 & 0.13 & 412.60 & 2973 & 99.25 \\
\hline $32-1,75$ & B & 50.27 & 14.35 & 11.60 & 7.36 & 11.65 & 2.26 & 0.09 & 1.56 & 0.14 & 412.84 & 2855 & 99.28 \\
\hline $34-5,109$ & B & 50.40 & 14.47 & 11.66 & 7.45 & 11.75 & 2.29 & 0.09 & 1.54 & 0.14 & 435.38 & 2856 & 99.79 \\
\hline $34-5,115$ & B & 50.75 & 14.21 & 11.45 & 6.99 & 11.73 & 2.35 & 0.13 & 1.61 & 0.14 & 435.43 & 2910 & 99.36 \\
\hline $34-7,17$ & C & 51.34 & 14.47 & 11.69 & 7.17 & 11.88 & 2.37 & 0.11 & 1.65 & 0.15 & 437.11 & 2857 & 100.83 \\
\hline $35-2,110$ & C & 51.18 & 14.18 & 11.64 & 6.93 & 11.79 & 2.26 & 0.11 & 1.66 & 0.15 & 439.85 & 2858 & 99.90 \\
\hline $35-3,80$ & C & 50.74 & 14.32 & 11.54 & 7.13 & 11.77 & 2.32 & 0.10 & 1.70 & 0.15 & 440.80 & 2911 & 99.77 \\
\hline $35-5,9$ & C & 50.42 & 14.22 & 11.80 & 7.20 & 11.65 & 2.26 & 0.09 & 1.66 & 0.12 & 442.61 & 2859 & 99.42 \\
\hline $36-1,62$ & C & 50.18 & 14.42 & 11.48 & 7.13 & 11.71 & 2.30 & 0.09 & 1.64 & 0.12 & 446.01 & 2860 & 99.07 \\
\hline $36-4,92$ & C & 50.56 & 14.53 & 11.49 & 7.20 & 11.77 & 2.34 & 0.08 & 1.61 & 0.13 & 450.00 & 2861 & 99.71 \\
\hline $37-2,38$ & C & 50.47 & 14.35 & 11.55 & 7.20 & 11.77 & 2.32 & 0.09 & 1.59 & 0.15 & 452.70 & 2862 & 99.49 \\
\hline $37-5,68$ & C & 50.53 & 14.32 & 11.68 & 7.04 & 11.89 & 2.30 & 0.11 & 1.64 & 0.17 & 456.21 & 2912 & 99.68 \\
\hline $38-1,85$ & C & 50.53 & 14.43 & 11.57 & 7.15 & 11.78 & 2.31 & 0.11 & 1.64 & 0.13 & 458.95 & 2863 & 99.65 \\
\hline $38-2,149$ & C & 50.91 & 14.25 & 11.56 & 7.22 & 11.75 & 2.31 & 0.12 & 1.64 & 0.17 & 460.26 & 2981 & 99.93 \\
\hline $38-6,76$ & C & 50.98 & 14.15 & 11.90 & 7.01 & 11.84 & 2.32 & 0.10 & 1.71 & 0.14 & 464.74 & 2913 & 100.15 \\
\hline $39-2,79$ & C & 49.95 & 13.90 & 11.58 & 6.96 & 11.68 & 2.42 & 0.11 & 1.67 & 0.16 & 466.49 & 3036 & 98.43 \\
\hline $39-4,75$ & C & 50.75 & 14.37 & 11.48 & 7.20 & 11.92 & 2.26 & 0.09 & 1.57 & 0.13 & 468.80 & 2864 & 99.77 \\
\hline $40-2,111$ & C & 50.69 & 14.58 & 11.63 & 7.28 & 11.96 & 2.30 & 0.11 & 1.61 & 0.13 & 473.61 & 2914 & 100.29 \\
\hline $41-1,30$ & C & 51.47 & 14.25 & 11.56 & 7.26 & 12.02 & 2.33 & 0.09 & 1.61 & 0.13 & 475.8 & 2915 & 100.72 \\
\hline $41-4,107$ & D & 50.78 & 14.14 & 11.09 & 7.20 & 11.97 & 2.25 & 0.09 & 1.53 & 0.14 & 480.28 & 2865 & 99.19 \\
\hline $42-2,10$ & D & 50.43 & 14.43 & 11.11 & 7.39 & 12.18 & 2.29 & 0.09 & 1.47 & 0.13 & 486.27 & 2916 & 99.52 \\
\hline $42-5,115$ & E & 50.54 & 14.21 & 11.68 & 6.88 & 11.86 & 2.37 & 0.09 & 1.71 & 0.12 & 491.71 & 2866 & 99.46 \\
\hline $42-6,120$ & E & 51.14 & 14.20 & 11.65 & 7.03 & 11.79 & 2.35 & 0.10 & 1.74 & 0.15 & 493.23 & 2917 & 100.15 \\
\hline $43-1,120$ & E & 50.75 & 14.21 & 11.80 & 7.07 & 11.87 & 2.33 & 0.12 & 1.71 & 0.15 & 494.92 & 2918 & 100.01 \\
\hline $43-1,130$ & E & 50.75 & 13.99 & 11.73 & 7.12 & 11.87 & 2.34 & 0.12 & 1.66 & 0.15 & 495.01 & 2980 & 99.73 \\
\hline $43-7,27$ & E & 50.52 & 13.80 & 11.73 & 7.14 & 11.74 & 2.33 & 0.09 & 1.65 & 0.12 & 502.42 & 2921 & 99.12 \\
\hline $44-4,5$ & E & 50.71 & 13.97 & 11.85 & 7.08 & 11.75 & 2.33 & 0.09 & 1.70 & 0.14 & 507.45 & 2923 & 99.62 \\
\hline $44-4,25$ & E & 50.46 & 13.92 & 11.77 & 6.94 & 11.77 & 2.34 & 0.10 & 1.71 & 0.16 & 507.65 & 2922 & 99.17 \\
\hline $52-4,24$ & F & 50.43 & 13.87 & 11.93 & 6.89 & 11.53 & 2.35 & 0.07 & 1.75 & 0.17 & 562.50 & 2871 & 98.99 \\
\hline $53-1,5$ & F & 50.52 & $14.2 \mathrm{C}$ & 11.75 & 6.91 & 11.75 & 2.35 & 0.09 & 1.78 & 0.14 & 567.55 & 2872 & 99.49 \\
\hline $53-2,65$ & F & 50.19 & 14.07 & 11.77 & 6.72 & 11.60 & 2.39 & 0.08 & 1.86 & 0.13 & 569.70 & 2873 & 98.81 \\
\hline $54-2,105$ & F & 50.67 & 13.95 & 11.96 & 6.67 & 11.57 & 2.38 & 0.08 & 1.81 & 0.15 & 579.55 & 2874 & 99.24 \\
\hline $54-3,17$ & F & 50.47 & 13.98 & 11.80 & 6.83 & 11.48 & 2.40 & 0.08 & 1.74 & 0.14 & 580.17 & 2875 & 98.92 \\
\hline $54-4,10$ & F & 50.63 & 13.91 & 12.19 & 7.09 & 11.60 & 2.32 & 0.08 & 1.77 & 0.14 & 581.60 & 2876 & 99.73 \\
\hline $54-6,135$ & F & 50.59 & 13.83 & 12.15 & 6.94 & 11.62 & 2.32 & 0.08 & 1.81 & 0.15 & 585.85 & 2877 & 99.49 \\
\hline $55-1,25$ & F & 51.07 & 14.04 & 11.91 & 6.75 & 11.72 & 2.38 & 0.09 & 1.82 & 0.15 & 586.75 & 2878 & 99.93 \\
\hline $55-2,30$ & $\mathrm{~F}$ & 51.35 & 13.69 & 11.93 & 6.98 & 11.60 & 2.35 & 0.08 & 1.80 & 0.15 & 588.30 & 2879 & 99.93 \\
\hline $55-3,5$ & F & 50.50 & 13.96 & 12.27 & 6.59 & 11.59 & 2.35 & 0.07 & 1.81 & 0.16 & 589.55 & 2880 & 99.30 \\
\hline $60-6,30$ & G & 51.08 & 14.65 & 11.26 & 7.34 & 11.72 & 2.27 & 0.12 & 1.45 & 0.13 & 638.62 & 2881 & 100.02 \\
\hline $62-1,4$ & H & 51.30 & 14.29 & 11.65 & 7.02 & 11.71 & 2.36 & 0.10 & 1.64 & 0.13 & 642.0 & 2882 & 100.20 \\
\hline $62 \cdot 2,15$ & $\mathrm{H}$ & 50.96 & 14.29 & 11.50 & 7.01 & 11.63 & 2.37 & 0.10 & 1.72 & 0.15 & 643.50 & 2883 & 99.73 \\
\hline $62-4,30$ & H & 50.69 & 14.12 & 11.91 & 7.16 & 11.49 & 2.33 & 0.09 & 1.63 & 0.16 & 646.37 & 2884 & 99.58 \\
\hline $62-6,77$ & H & 51.08 & 14.26 & 11.68 & 6.97 & 11.72 & 2.36 & 0.11 & 1.65 & 0.14 & 649.52 & 2885 & 99.97 \\
\hline $63-2,97$ & H & 51.07 & 14.35 & 11.31 & 7.00 & 11.59 & 2.34 & 0.11 & 1.65 & 0.13 & 653.47 & 2886 & 99.55 \\
\hline $63-4,134$ & H & 50.75 & 14.30 & 11.66 & 7.07 & 11.54 & 2.34 & 0.11 & 1.60 & 0.14 & 656.84 & 2887 & 99.51 \\
\hline $64-1,110$ & H & 50.45 & 14.34 & 11.28 & 6.93 & 11.59 & 2.38 & 0.11 & 1.64 & 0.16 & 661.10 & 2889 & 98.88 \\
\hline $64-4,70$ & H & 50.91 & 14.40 & 11.39 & 7.11 & 11.68 & 2.40 & 0.09 & 1.59 & 0.12 & 665.20 & 2890 & 99.69 \\
\hline $64-4,74$ & $\mathrm{H}$ & 50.18 & 14.14 & 11.70 & 7.17 & 11.50 & 2.32 & 0.09 & 1.59 & 0.14 & 665.24 & 2891 & 98.83 \\
\hline $64-4,127$ & H & 50.48 & 14.41 & 11.67 & 7.27 & 11.71 & 2.32 & 0.09 & 1.62 & 0.13 & 665.77 & 2892 & 99.70 \\
\hline $66-2,32$ & H & 51.07 & 14.41 & 11.76 & 7.27 & 11.75 & 2.31 & 0.09 & 1.58 & 0.14 & 679.82 & 2894 & 100.38 \\
\hline $66-4,74$ & H & 50.25 & 14.45 & 11.80 & 7.31 & 11.60 & 2.32 & 0.09 & 1.59 & 0.14 & 683.24 & 2895 & 99.55 \\
\hline $66-6,3$ & H & 50.52 & 14.42 & 11.32 & 7.11 & 11.61 & 2.35 & 0.08 & 1.55 & 0.13 & 685.53 & 2896 & 99.09 \\
\hline $66-6,50$ & H & 50.67 & 14.51 & 11.57 & 7.41 & 11.74 & 2.34 & 0.08 & 1.57 & 0.14 & 686.00 & 2897 & 100.03 \\
\hline $66-6,60$ & H & 50.43 & 14.17 & 11.51 & 7.16 & 11.80 & 2.32 & 0.08 & 1.63 & 0.15 & 686.10 & 2898 & 99.25 \\
\hline
\end{tabular}


TABLE 1B

Chemistry Versus Depth, DSDP Holes 418A and 418B

\begin{tabular}{|c|c|c|c|c|c|c|c|c|c|c|c|c|c|}
\hline $\begin{array}{c}\text { Sample } \\
\text { (Interval in } \mathrm{cm} \text { ) }\end{array}$ & $\begin{array}{c}\text { Chemical } \\
\text { Type }\end{array}$ & $\mathrm{SiO}_{2}$ & $\mathrm{Al}_{2} \mathrm{O}_{3}$ & $\mathrm{FeOT}$ & $\mathrm{MgO}$ & $\mathrm{CaO}$ & $\mathrm{Na}_{2} \mathrm{O}$ & $\mathrm{K}_{2} \mathrm{O}$ & $\mathrm{TiO}_{2}$ & $\mathrm{P}_{2} \mathrm{O}_{5}$ & $\begin{array}{l}\text { Sub-Bottom } \\
\text { Depth }(m)\end{array}$ & VGM & Total \\
\hline \multicolumn{14}{|l|}{ Hole 418A } \\
\hline $15-1,61$ & A & 51.05 & 14.53 & 10.20 & 7.73 & 12.44 & 2.23 & 0.09 & 1.23 & 0.11 & 320.61 & 2924 & 99.61 \\
\hline $15-1,144$ & A & 51.05 & 14.41 & 10.37 & 7.85 & 12.51 & 2.24 & 0.09 & 1.25 & 0.12 & 321.44 & 2925 & 99.89 \\
\hline $15-2,0$ & A & 51.06 & 14.81 & 9.98 & 7.55 & 12.25 & 2.36 & 0.10 & 1.22 & 0.13 & 321.50 & 3040 & 99.46 \\
\hline $15-2,123$ & A & 50.89 & 14.59 & 10.31 & 7.83 & 12.46 & 2.27 & 0.09 & 1.25 & 0.11 & 322.73 & 2926 & 99.80 \\
\hline $15-3,59$ & A & 50.52 & 14.72 & 10.18 & 7.82 & 12.45 & 2.26 & 0.09 & 1.24 & 0.12 & 323.58 & 2927 & 99.40 \\
\hline $20-5,84$ & A & 51.79 & 14.18 & 10.58 & 7.73 & 12.68 & 1.96 & 0.11 & 1.24 & 0.11 & 363.16 & 2928 & 100.38 \\
\hline $23-1,15$ & A & 50.86 & 14.44 & 10.13 & 7.75 & 12.43 & 2.31 & 0.12 & 1.27 & 0.11 & 375.65 & 2929 & 99.42 \\
\hline $25-1,78$ & A & 51.15 & 14.15 & 10.17 & 7.42 & 12.44 & 2.08 & 0.10 & 1.27 & 0.10 & 382.17 & 2930 & 98.88 \\
\hline $25-2,18$ & A & 51.75 & 14.43 & 10.30 & 7.50 & 12.26 & 2.24 & 0.09 & 1.24 & 0.10 & 382.94 & 2931 & 99.91 \\
\hline $25-2,51$ & A & 51.31 & 14.10 & 10.59 & 7.61 & 12.28 & 2.19 & 0.09 & 1.34 & 0.10 & 383.22 & 2932 & 99.61 \\
\hline $25-2,57$ & A & 51.68 & 14.45 & 10.32 & 7.52 & 12.22 & 2.26 & 0.11 & 1.28 & 0.11 & 383.27 & 2933 & 99.95 \\
\hline $25-2,57$ & A & 50.70 & 13.52 & 10.56 & 7.70 & 12.25 & 2.09 & 0.10 & 1.33 & 0.12 & 383.27 & 2935 & 98.37 \\
\hline $28-5,3$ & B & 50.76 & 14.90 & 10.50 & 7.69 & 12.16 & 2.22 & 0.07 & 1.30 & 0.09 & 408.53 & 2934 & 99.69 \\
\hline $30-1,89$ & B & 51.08 & 14.83 & 10.45 & 7.51 & 12.27 & 2.26 & 0.07 & 1.37 & 0.10 & 415.39 & 2936 & 99.94 \\
\hline $30-2,75$ & B & 50.84 & 14.63 & 10.55 & 7.82 & 12.17 & 2.23 & 0.08 & 1.33 & 0.09 & 416.25 & 2937 & 99.74 \\
\hline $30-2,143$ & B & 50.59 & 14.61 & 10.34 & 7.50 & 12.38 & 2.31 & 0.09 & 1.35 & 0.10 & 417.43 & 2938 & 99.27 \\
\hline $30-3,004$ & B & 51.15 & 14.63 & 10.46 & 7.67 & 12.08 & 2.30 & 0.08 & 1.29 & 0.11 & 417.54 & 2939 & 99.77 \\
\hline $30-3,36$ & B & 51.20 & 14.77 & 10.17 & 7.55 & 12.23 & 2.25 & 0.09 & 1.31 & 0.13 & 417.86 & 2940 & 99.70 \\
\hline $34-3,20$ & B & 51.37 & 14.68 & 9.84 & 7.47 & 12.21 & 2.29 & 0.09 & 1.34 & 0.13 & 452.20 & 2941 & 99.42 \\
\hline $42-3,17$ & C & 50.80 & 15.55 & 9.77 & 8.37 & 12.70 & 2.19 & 0.06 & 1.14 & 0.13 & 509.67 & 2942 & 100.71 \\
\hline $42-3,25$ & C & 50.53 & 15.51 & 9.68 & 8.21 & 12.69 & 2.23 & 0.05 & 1.11 & 0.11 & 509.75 & 2943 & 100.12 \\
\hline $42-3,68$ & C & 49.57 & 15.67 & 9.58 & 8.30 & 12.44 & 2.28 & 0.06 & 1.12 & 0.10 & 510.18 & 3041 & 99.12 \\
\hline $42-3,118$ & C & 50.43 & 15.47 & 9.71 & 8.10 & 12.61 & 2.21 & 0.06 & 1.11 & 0.11 & 511.68 & 2944 & 99.81 \\
\hline $42-4,107$ & C & 50.25 & 15.49 & 9.71 & 8.22 & 12.64 & 2.21 & 0.06 & 1.14 & 0.11 & 513.07 & 2945 & 99.83 \\
\hline $43-1,71$ & C & 49.90 & 15.26 & 9.77 & 8.33 & 12.62 & 2.19 & 0.05 & 1.13 & 0.09 & 517.21 & 2946 & 99.34 \\
\hline $43-2,133$ & C & 50.36 & 15.51 & 9.59 & 8.26 & 12.46 & 2.25 & 0.05 & 1.11 & 0.11 & 519.03 & 2947 & 99.70 \\
\hline $43-3,74$ & C & 50.47 & 15.47 & 9.73 & 8.33 & 12.58 & 2.21 & 0.06 & 1.14 & 0.11 & 520.24 & 2948 & 100.10 \\
\hline $44-1,26$ & C & 50.39 & 15.51 & 9.71 & 8.26 & 12.66 & 2.22 & 0.06 & 1.11 & 0.09 & 525.76 & 2949 & 100.01 \\
\hline $44-2,64$ & C & 50.08 & 15.63 & 9.75 & 8.43 & 12.63 & 2.19 & 0.05 & 1.15 & 0.09 & 527.64 & 2950 & 100.00 \\
\hline $44-3,73$ & C & 50.16 & 15.43 & 9.81 & 8.30 & 12.57 & 2.17 & 0.05 & 1.15 & 0.09 & 529.23 & 2951 & 99.73 \\
\hline $44-4,113$ & D & 49.91 & 15.40 & 10.04 & 8.13 & 12.45 & 2.23 & 0.05 & 1.22 & 0.11 & 531.13 & 2952 & 99.54 \\
\hline $44-5,94$ & D & 50.06 & 15.36 & 9.99 & 8.17 & 12.42 & 2.22 & 0.05 & 1.22 & 0.09 & 532.44 & 2953 & 99.58 \\
\hline $45-1,38$ & D & 49.65 & 15.40 & 9.98 & 8.00 & 12.34 & 2.25 & 0.05 & 1.22 & 0.11 & 534.88 & 2954 & 99.00 \\
\hline $45 \cdot 2,37$ & D & 50.08 & 15.44 & 10.07 & 8.11 & 12.19 & 2.23 & 0.06 & 1.18 & 0.12 & 536.37 & 3042 & 99.48 \\
\hline $45-2,131$ & D & 50.35 & 15.26 & 10.06 & 8.18 & 12.46 & 2.24 & 0.05 & 1.22 & 0.11 & 537.31 & 2955 & 99.93 \\
\hline $45-3,108$ & D & 49.84 & 15.20 & 10.17 & 8.08 & 12.44 & 2.23 & 0.06 & 1.22 & 0.11 & 538.54 & 2956 & 99.35 \\
\hline $45-4,115$ & D & 50.52 & 15.41 & 10.04 & 8.14 & 12.52 & 2.28 & 0.05 & 1.23 & 0.11 & 540.15 & 2957 & 100.30 \\
\hline $45-5,106$ & D & 50.14 & 15.34 & 10.13 & 8.03 & 12.49 & 2.28 & 0.06 & 1.19 & 0.11 & 541.56 & 2958 & 99.77 \\
\hline $46-1,39$ & D & 50.03 & 15.34 & 10.12 & 7.91 & 12.31 & 2.28 & 0.06 & 1.20 & 0.09 & 543.89 & 2959 & 99.34 \\
\hline $46-2,113$ & D & 50.70 & 15.20 & 10.21 & 7.95 & 12.53 & 2.26 & 0.06 & 1.25 & 0.12 & 546.13 & 2960 & 100.28 \\
\hline $46-3,56$ & D & 49.92 & 15.27 & 10.03 & 7.97 & 12.42 & 2.26 & 0.05 & 1.23 & 0.12 & 547.06 & 2961 & 99.27 \\
\hline $46-4,41$ & D & 50.35 & 15.24 & 10.25 & 7.92 & 12.39 & 2.26 & 0.06 & 1.26 & 0.12 & 548.41 & 2962 & 99.85 \\
\hline $46-5,3$ & D & 50.21 & 15.30 & 10.31 & 8.09 & 12.46 & 2.21 & 0.06 & 1.26 & 0.11 & 549.53 & 2963 & 100.01 \\
\hline $47-1,52$ & D & 50.18 & 15.17 & 10.24 & 8.03 & 12.37 & 2.22 & 0.06 & 1.24 & 0.09 & 553.02 & 2964 & 99.60 \\
\hline $47-2,81$ & D & 50.06 & 15.16 & 10.07 & 7.90 & 12.38 & 2.23 & 0.06 & 1.25 & 0.10 & 554.81 & 2965 & 99.21 \\
\hline $47-3,4$ & D & 50.22 & 15.40 & 10.39 & 8.03 & 12.39 & 2.21 & 0.07 & 1.26 & 0.11 & 555.54 & 2966 & 100.08 \\
\hline $47-5,3$ & D & 50.11 & 15.08 & 10.32 & 7.93 & 12.41 & 2.26 & 0.06 & 1.27 & 0.11 & 558.53 & 2968 & 99.55 \\
\hline $48-1,130$ & D & 50.08 & 14.98 & 10.60 & 8.06 & 12.39 & 2.19 & 0.05 & 1.24 & 0.10 & 562.80 & 2969 & 99.69 \\
\hline $48-3,46$ & D & 49.78 & 15.31 & 10.07 & 7.64 & 12.23 & 2.27 & 0.06 & 1.24 & 0.11 & 564.96 & 2970 & 98.71 \\
\hline $48-4,51$ & D & 50.35 & 15.26 & 10.27 & 7.80 & 12.32 & 2.23 & 0.07 & 1.31 & 0.10 & 566.51 & 2971 & 99.71 \\
\hline $48-5,28$ & E & 50.02 & 15.29 & 10.27 & 7.85 & 12.25 & 2.23 & 0.06 & 1.23 & 0.10 & 567.78 & 2972 & 99.30 \\
\hline $49-1,10$ & E & 50.27 & 15.27 & 10.29 & 7.92 & 12.47 & 2.27 & 0.08 & 1.22 & 0.12 & 570.59 & 2982 & 99.91 \\
\hline $49-1,77$ & E & 50.49 & 15.10 & 10.38 & 8.01 & 12.45 & 2.21 & 0.08 & 1.20 & 0.13 & 571.18 & 2983 & 100.05 \\
\hline $50-2,24$ & E & 49.77 & 15.21 & 10.09 & 8.06 & 12.33 & 2.26 & 0.11 & 1.20 & 0.10 & 575.24 & 3024 & 99.13 \\
\hline $50-2,79$ & E & 50.33 & 15.63 & 10.42 & 8.09 & 12.38 & 2.31 & 0.07 & 1.22 & 0.11 & 575.79 & 3043 & 100.56 \\
\hline $50-4,27$ & E & 50.73 & 15.26 & 10.13 & 7.93 & 12.30 & 2.21 & 0.09 & 1.23 & 0.10 & 578.27 & 2985 & 99.98 \\
\hline $50-5,52$ & E & 50.70 & 15.18 & 10.39 & 7.99 & 12.36 & 2.21 & 0.08 & 1.22 & 0.10 & 580.02 & 2986 & 100.23 \\
\hline $51-3,23$ & E & 51.09 & 15.45 & 10.58 & 8.13 & 12.32 & 2.20 & 0.08 & 1.28 & 0.10 & 586.13 & 2987 & 101.23 \\
\hline $52-5,75$ & $\mathrm{E}$ & 50.55 & 14.92 & 10.47 & 8.02 & 12.20 & 2.31 & 0.10 & 1.23 & 0.10 & 598.34 & 3021 & 99.90 \\
\hline $53-1,125$ & E & 50.58 & 15.19 & 10.69 & 7.72 & 12.30 & 2.41 & 0.09 & 1.28 & 0.12 & 602.85 & 3044 & 100.38 \\
\hline $54-2.68$ & $\mathrm{~F}$ & 50.58 & 14.21 & 11.46 & 7.21 & 11.70 & 2.31 & 0.11 & 1.57 & 0.12 & 613.18 & 3026 & 99.27 \\
\hline $55-4,112$ & G & 50.70 & 14.60 & 10.52 & 7.38 & 12.38 & 2.33 & 0.11 & 1.37 & 0.13 & 625.51 & 3033 & 99.52 \\
\hline $55-5,110$ & G & 50.54 & 14.40 & 10.64 & 7.49 & 12.22 & 2.26 & 0.11 & 1.39 & 0.14 & 626.86 & 3034 & 99.19 \\
\hline $55-6,15$ & G & 51.24 & 14.65 & 10.61 & 7.61 & 12.06 & 2.38 & 0.11 & 1.38 & 0.13 & 627.36 & 3020 & 100.17 \\
\hline $56-5,129$ & $\mathrm{H}$ & 49.99 & 14.17 & 11.43 & 7.05 & 11.66 & 2.38 & 0.14 & 1.54 & 0.12 & 636.29 & 3022 & 98.48 \\
\hline $57-2.113$ & $\mathrm{H}$ & 50.66 & 14.22 & 11.31 & 7.32 & 11.68 & 2.37 & 0.14 & 1.57 & 0.12 & 641.63 & 3025 & 99.39 \\
\hline $57-4,80$ & $\mathrm{H}$ & 50.95 & 14.06 & 11.70 & 7.15 & 11.92 & 2.37 & 0.12 & 1.60 & 0.12 & 644.30 & 2989 & 99.99 \\
\hline $58-1,56$ & $\mathrm{H}$ & 50.45 & 14.46 & 11.85 & 6.95 & 11.56 & 2.41 & 0.11 & 1.64 & 0.16 & 648.67 & 3045 & 99.59 \\
\hline $58-2,21$ & $\mathrm{H}$ & 50.36 & 14.66 & 11.84 & 6.92 & 11.50 & 2.47 & 0.12 & 1.67 & 0.15 & 649.91 & 3046 & 99.69 \\
\hline $58-2.28$ & $\mathrm{H}$ & 50.67 & 13.99 & 11.76 & 6.81 & 11.57 & 2.45 & 0.12 & 1.74 & 0.15 & 649.98 & 2990 & 99.26 \\
\hline $58-2.32$ & $\mathrm{H}$ & 51.22 & 14.28 & 12.08 & 7.00 & 11.57 & 2.38 & 0.13 & 1.77 & 0.16 & 650.02 & 2991 & 100.59 \\
\hline $58-3,50$ & $\mathrm{H}$ & 50.94 & 14.22 & 11.72 & 6.88 & 11.57 & 2.46 & 0.13 & 1.73 & 0.15 & 651.70 & 2992 & 99.80 \\
\hline
\end{tabular}


TABLE 1B - Continued

\begin{tabular}{|c|c|c|c|c|c|c|c|c|c|c|c|c|c|}
\hline $\begin{array}{c}\text { Sample } \\
\text { (Interval in } \mathrm{cm} \text { ) }\end{array}$ & $\begin{array}{l}\text { Chemical } \\
\text { Type }\end{array}$ & $\mathrm{SiO}_{2}$ & $\mathrm{Al}_{2} \mathrm{O}_{3}$ & FeOT & $\mathrm{MgO}$ & $\mathrm{CaO}$ & $\mathrm{Na}_{2} \mathrm{O}$ & $\mathrm{K}_{2} \mathrm{O}$ & $\mathrm{TiO}_{2}$ & $\mathrm{P}_{2} \mathrm{O}_{5}$ & $\begin{array}{l}\text { Sub-Bottom } \\
\text { Depth }(m)\end{array}$ & VGM & Total \\
\hline $59-3,11$ & $\mathrm{H}$ & 50.64 & 14.23 & 11.74 & 6.84 & 11.58 & 2.41 & 0.13 & 1.75 & 0.14 & 660.23 & 2993 & 99.46 \\
\hline $59-4,3$ & $\mathrm{H}$ & 50.93 & 14.38 & 11.77 & 6.88 & 11.83 & 2.51 & 0.14 & 1.72 & 0.14 & 661.52 & 2994 & 100.30 \\
\hline $59-6,16$ & $\mathrm{H}$ & 51.04 & 14.15 & 11.73 & 6.99 & 11.46 & 2.42 & 0.11 & 1.71 & 0.13 & 664.31 & 2995 & 99.74 \\
\hline $60-1,84$ & $\mathrm{H}$ & 50.42 & 14.37 & 11.45 & 7.09 & 11.47 & 2.48 & 0.15 & 1.65 & 0.13 & 667.84 & 3023 & 99.21 \\
\hline $60-2,66$ & $\mathrm{H}$ & 50.47 & 14.25 & 11.72 & 6.96 & 11.60 & 2.39 & 0.13 & 1.68 & 0.15 & 669.16 & 2996 & 99.35 \\
\hline $60-3,34$ & $\mathrm{H}$ & 50.24 & 14.22 & 11.57 & 6.87 & 11.63 & 2.45 & 0.13 & 1.65 & 0.17 & 670.34 & 3037 & 98.93 \\
\hline $62-1,27$ & $\mathrm{H}$ & 50.87 & 14.39 & 11.74 & 7.05 & 11.76 & 2.40 & 0.12 & 1.71 & 0.16 & 686.16 & 2997 & 100.20 \\
\hline $62-2,73$ & $\mathrm{H}$ & 50.77 & 14.37 & 11.47 & 6.92 & 11.57 & 2.44 & 0.12 & 1.70 & 0.17 & 687.32 & 2998 & 99.53 \\
\hline $62-4,64$ & $\mathrm{H}$ & 49.99 & 14.66 & 11.60 & 7.07 & 11.50 & 2.35 & 0.10 & 1.60 & 0.16 & 689.03 & 3047 & 99.03 \\
\hline $62-4,104$ & $\mathrm{H}$ & 50.44 & 14.40 & 11.46 & 6.99 & 11.64 & 2.44 & 0.12 & 1.68 & 0.14 & 689.27 & 2999 & 99.31 \\
\hline $63-1,36$ & $\mathrm{H}$ & 50.27 & 14.52 & 11.49 & 6.88 & 11.64 & 2.49 & 0.13 & 1.65 & 0.15 & 690.27 & 3000 & 99.22 \\
\hline $64-2,19$ & I & 50.55 & 14.88 & 10.83 & 7.50 & 12.23 & 2.39 & 0.08 & 1.40 & 0.12 & 697.19 & 3048 & 99.98 \\
\hline $64-3,50$ & I & 50.93 & 14.74 & 10.95 & 7.54 & 12.39 & 2.34 & 0.10 & 1.38 & 0.13 & 699.00 & 3001 & 100.50 \\
\hline $64-4,82$ & I & 49.99 & 15.00 & 10.58 & 7.58 & 11.90 & 2.39 & 0.10 & 1.34 & 0.13 & 700.82 & 3049 & 99.01 \\
\hline $64-6,42$ & I & 50.91 & 14.76 & 10.66 & 7.39 & 12.33 & 2.33 & 0.09 & 1.36 & 0.14 & 703.82 & 3002 & 99.97 \\
\hline $65-1,44$ & I & 50.69 & 14.58 & 10.67 & 7.38 & 12.14 & 2.30 & 0.09 & 1.32 & 0.14 & 705.54 & 3003 & 99.31 \\
\hline $65-1,111$ & I & 51.97 & 14.43 & 10.88 & 7.53 & 12.20 & 2.42 & 0.08 & 1.44 & 0.13 & 706.21 & 3050 & 101.08 \\
\hline $66-2,126$ & J & 51.07 & 14.33 & 11.27 & 7.05 & 11.92 & 2.38 & 0.10 & 1.55 & 0.14 & 717.36 & 3004 & 99.81 \\
\hline $66-4,65$ & J & 50.70 & 14.24 & 11.41 & 7.35 & 11.71 & 2.31 & 0.12 & 1.53 & 0.14 & 719.75 & 3028 & 99.51 \\
\hline $67-1,105$ & J & 51.19 & 14.39 & 11.48 & 7.16 & 12.07 & 2.37 & 0.11 & 1.55 & 0.14 & 725.15 & 3005 & 100.46 \\
\hline $67-4,35$ & J & 50.83 & 14.40 & 11.19 & 7.01 & 11.93 & 2.37 & 0.10 & 1.53 & 0.14 & 728.95 & 3006 & 99.50 \\
\hline $68-2,135$ & J & 51.47 & 14.26 & 11.38 & 7.11 & 11.97 & 2.37 & 0.10 & 1.55 & 0.16 & 731.95 & 3007 & 100.37 \\
\hline $69-2,10$ & J & 50.93 & 14.32 & 11.42 & 7.06 & 11.98 & 2.39 & 0.11 & 1.54 & 0.14 & 735.17 & 3008 & 99.89 \\
\hline $69-3,63$ & J & 52.02 & 13.94 & 11.55 & 7.23 & 11.81 & 2.42 & 0.11 & 1.59 & 0.14 & 737.16 & 3051 & 100.81 \\
\hline $70-2,86$ & J & 51.11 & 14.07 & 11.57 & 7.16 & 11.94 & 2.34 & 0.10 & 1.59 & 0.16 & 745.46 & 3010 & 100.04 \\
\hline $71-3,12$ & $\mathrm{~J}$ & 50.87 & 14.20 & 11.69 & 7.17 & 11.93 & 2.31 & 0.10 & 1.58 & 0.14 & 755.82 & 3011 & 99.99 \\
\hline $71-4,82$ & J & 51.15 & 14.32 & 11.42 & 7.20 & 11.91 & 2.35 & 0.10 & 1.56 & 0.14 & 758.02 & 3012 & 100.15 \\
\hline $72-4,4$ & J & 51.17 & 14.07 & 11.46 & 7.16 & 11.89 & 2.28 & 0.11 & 1.50 & 0.14 & 763.34 & 3013 & 99.78 \\
\hline $73-1,127$ & J & 50.77 & 14.15 & 10.99 & 7.15 & 11.62 & 2.35 & 0.12 & 1.48 & 0.11 & 766.07 & 3029 & 98.74 \\
\hline $73-2,83$ & J & 51.04 & 14.27 & 11.40 & 7.20 & 11.85 & 2.28 & 0.09 & 1.54 & 0.16 & 767.13 & 3014 & 99.83 \\
\hline $73-4,38$ & J & 50.58 & 14.20 & 10.97 & 7.07 & 11.88 & 2.34 & 0.10 & 1.53 & 0.14 & 769.68 & 3030 & 98.81 \\
\hline $74-4,44$ & J & 51.18 & 14.10 & 11.31 & 7.00 & 11.80 & 2.37 & 0.11 & 1.55 & 0.16 & 778.25 & 3015 & 99.58 \\
\hline $74-5,5$ & J & 51.10 & 14.00 & 11.23 & 7.01 & 11.84 & 2.30 & 0.12 & 1.55 & 0.14 & 779.14 & 3016 & 99.29 \\
\hline $75-4,140$ & J & 50.74 & 14.24 & 10.76 & 7.12 & 11.78 & 2.36 & 0.12 & 1.48 & 0.15 & 786.42 & 3017 & 98.75 \\
\hline $75-5,67$ & $\mathrm{~J}$ & 50.55 & 13.98 & 11.02 & 7.17 & 11.74 & 2.32 & 0.12 & 1.50 & 0.14 & 787.04 & 3018 & 98.54 \\
\hline $76-1,4$ & $\mathrm{~K}$ & 50.73 & 14.34 & 10.59 & 7.37 & 11.72 & 2.39 & 0.11 & 1.44 & 0.12 & 787.14 & 3027 & 98.81 \\
\hline $79-4,88$ & L & 52.14 & 13.92 & 11.69 & 7.21 & 11.84 & 2.42 & 0.08 & 1.55 & 0.15 & 817.00 & 3052 & 101.00 \\
\hline $80-1,6$ & M & 49.79 & 15.18 & 9.98 & 7.92 & 12.30 & 2.25 & 0.08 & 1.21 & 0.12 & 821.56 & 3031 & 98.83 \\
\hline $86-5,29$ & $\mathrm{~N}$ & 50.76 & 14.31 & 10.16 & 7.41 & 12.11 & 2.23 & 0.12 & 1.32 & 0.16 & 865.79 & 3032 & 98.58 \\
\hline \multicolumn{14}{|l|}{ Hole 418B } \\
\hline $35-5,78$ & $\mathrm{O}$ & 50.93 & 14.73 & 9.99 & 7.50 & 12.36 & 2.29 & 0.10 & 1.26 & 0.11 & 326.78 & 3035 & 99.27 \\
\hline
\end{tabular}

features have been interpreted as single eruptive events in the deep holes of DSDP Leg 37 (Hall and Ryall, 1977; Byerly and Wright, 1978).

In this paper, we define chemical type as all analyses within a continuous stratigraphic sequence which agree approximately within the estimated error of analysis. Adjacent sets of analyses which appeared to differ by more than the estimated error of the analyses were put into two separate chemical types. For groups which differed by amounts close to the precision of the data, the analysis number (VGM, Tables 1A, B) was checked to allow comparison of samples analyzed at the same time. Slight differences between adjacent sets of data could be attributed to the analytical differences between two separate analytical runs. Averages and standard deviations are given for each chemical type of more than two samples (Table 2). Based on a $t$-test with pooled standard error, at least one oxide differs significantly at the 95 per cent confidence level in tests between adjacent chemical types. In most tests, two or more oxides vary at the 95 per cent confidence level. The comparison of types 417D-A and B is just significant for $\mathrm{MgO}$ and the comparison of types 418A-D and $\mathrm{E}$ is just significant for total $\mathrm{FeO}$. In both cases, these two chemical types could justifiably be lumped together because of the uncertainties in the grouping procedure.

The concept of magma batch denotes two or more chemical types, within an essentially contiguous stratigraphic sequence, which can be related by fractional crystallization of observed equilibrium phenocrysts. This implies a lowpressure relationship, that is, a magma chamber residing within the oceanic crust. Fractional crystallization can be quantitatively modeled and, in the next section, relationships between chemical types are considered using a leastsquares procedure.

It should be noted that chemical units (both chemical types and magma batches) may not necessarily correspond to lithologic units or to magnetic units as defined onboard ship. Comparisons between these sets of units are made in a later section.

\section{FRACTIONAL CRYSTALLIZATION AND MAGMA BATCHES}

In the Hole 417D and 418A basalts, plagioclase and olivine were the most common phenocryst phases. About half of the recovered basalts contained augite as a phenocryst phase. Compositional and textural evidence sug- 

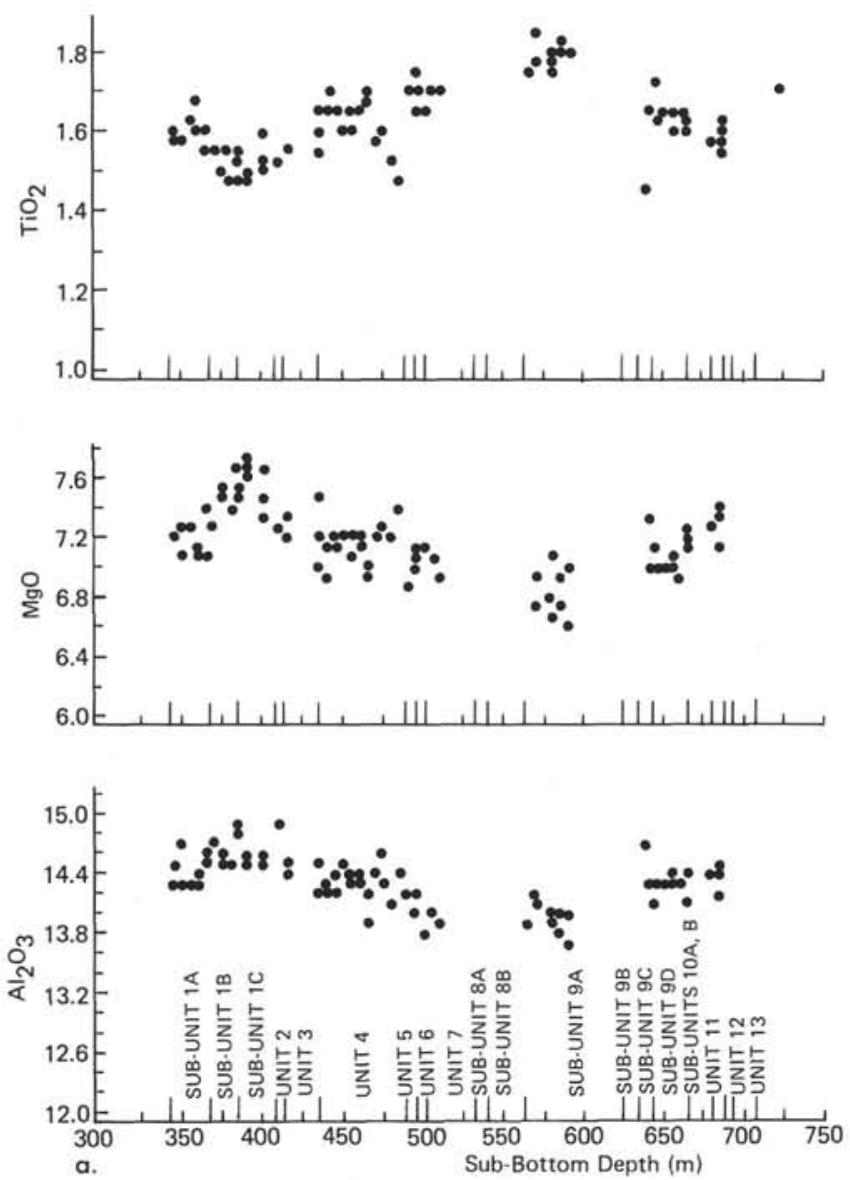

Figure 1. $(a, b, c)$ Major oxides determined by microprobe for Hole 417D natural glasses versus depth. Lithologic units are those defined in the Site 417 Site Report /this volume). Each point may represent more than one analysis.

gests that in many cases the phenocrysts are not in equilibrium with the liquids in which they reside (Sinton and Byerly, this volume). Plots of the chemical type averages determined above on $\mathrm{MgO}$ variation diagrams (Figure 3a, b, c, d) suggest that a single liquid trend exists for all of the chemical types encountered in the two holes. To test this, the most magnesian type (418A-C) was used as the parental liquid to each of the other chemical types in a least-squares analysis. Phenocryst compositions chosen were plagioclase ( $\mathrm{An}_{70}$ and $\mathrm{An}_{90}$ ), olivine ( $\mathrm{FO}_{70}$ and $\mathrm{Fog}_{90}$ ), and augite $\left(\mathrm{Wo}_{40} \mathrm{En}_{50} \mathrm{Fs}_{10}\right)$ from Sample 417D-45-2, $37 \mathrm{~cm}$. These compositions represent the range found in the two holes (Sinton and Byerly, this volume). The solutions to these least-squares comparisons are presented in Table 3, along with residuals considered to be significant and comments regarding deviations between the solutions and the observed phenocryst assemblages. Many of the leastsquares comparisons are favorable to the hypothesis of a single-liquid line of descent from a parental liquid such as 418A-C. The residuals are generally very low, and those listed in Table 3 are only marginally significant.

The most significant deviations from this simple model of one parent and one liquid line of descent are as follows: (1) $\mathrm{Na}_{2} \mathrm{O}, \mathrm{TiO}_{2}$, and $\mathrm{K}_{2} \mathrm{O}$ residuals are just at the level suggest-
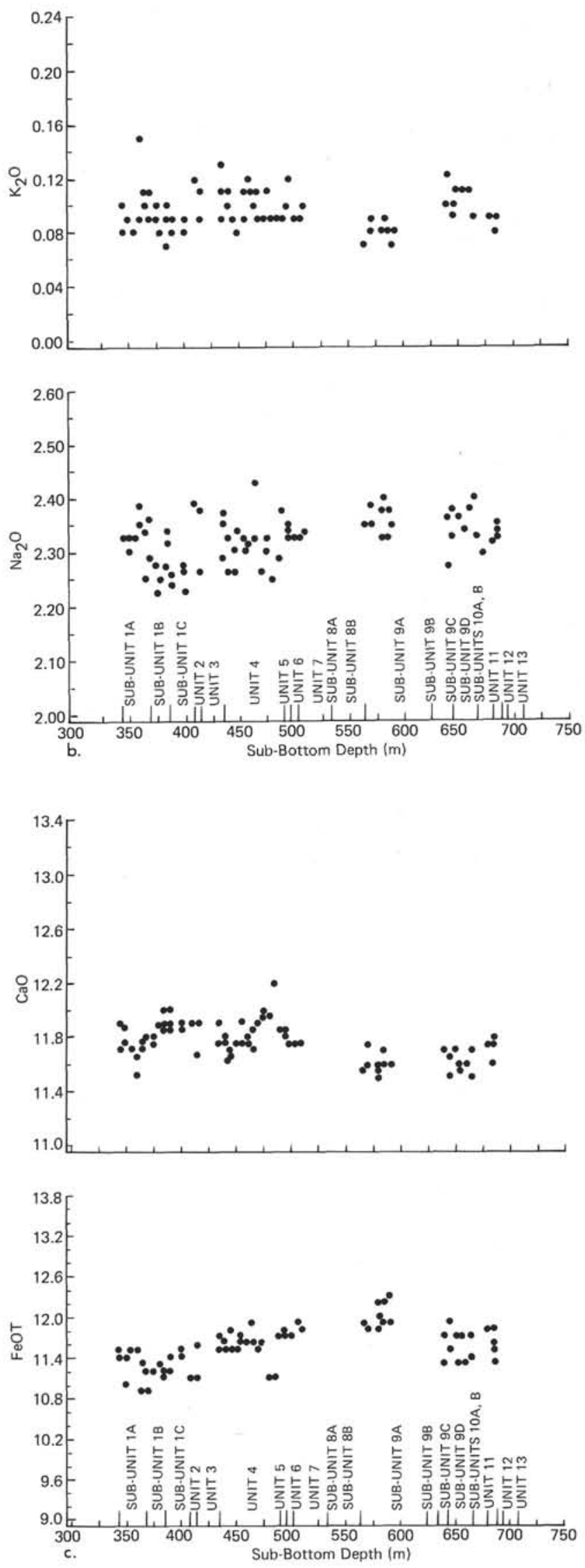

Figure 1. (Continued). 

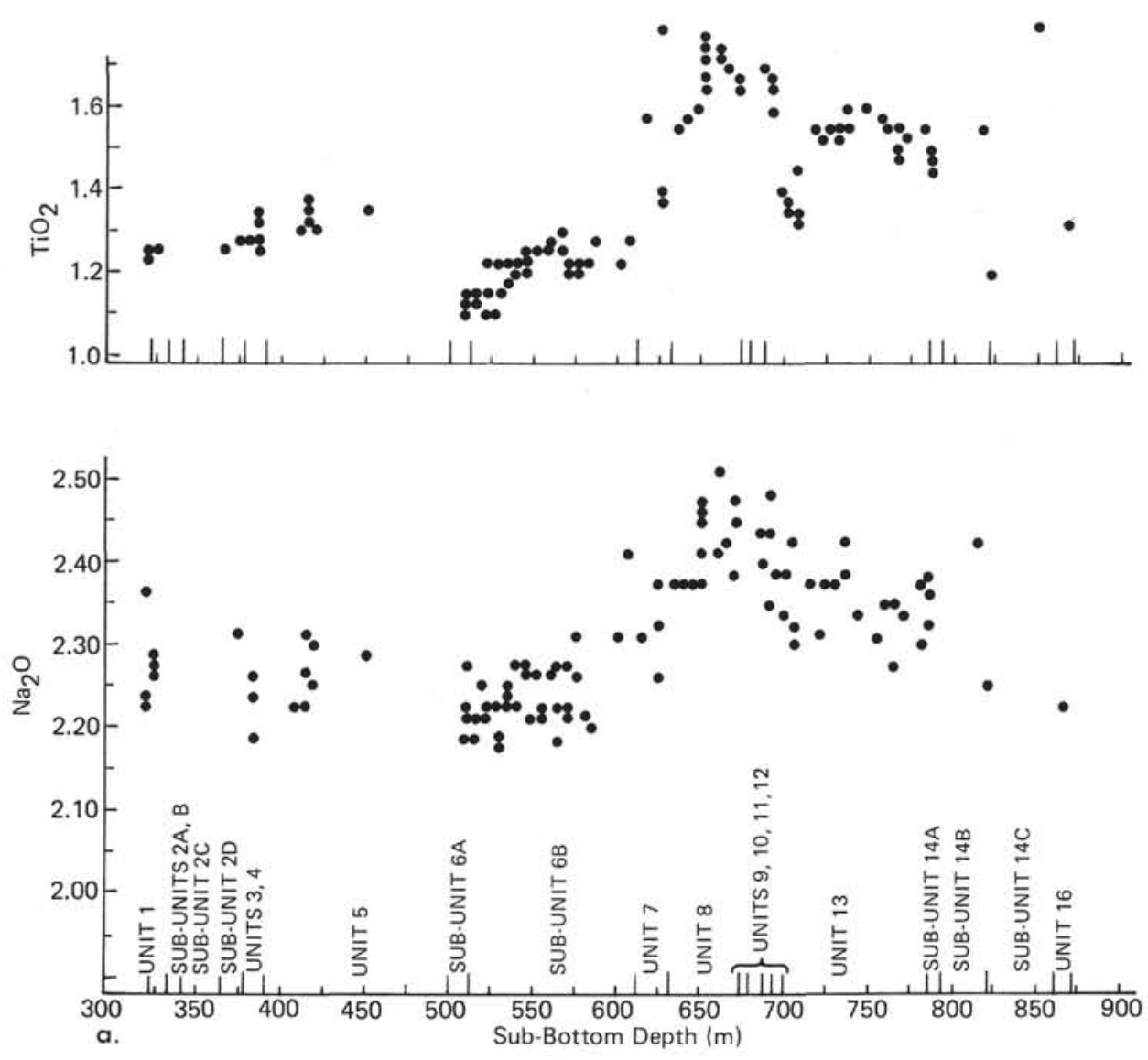

Figure 2. ( $a, b, c)$ Major oxides determined by microprobe for Hole $418 \mathrm{~A}$ natural glasses versus depth. Lithologic units are those defined in the Site 418 Site Report (this volume). Each point may represent more than one analysis.

ing two or more trends; and (2) for eight of these groups, little or no augite was found in the rocks as a phenocryst phase. Based on the similarity of residuals in Table 3 , a second set of least-squares comparisons was made using parental compositions 417D-B and E, 418A-B and G. The solutions to these are quite good and are consistent with the hypothesis of fractional crystallization to produce the groups of compositions observed. These solutions are used to make our final stratigraphic breakdown into magma batches. They are presented in Table 4 along with comments about possible similarities between physically separated chemical types or magma batches.

\section{COMPARISON OF CHEMICAL, LITHOLOGIC, AND MAGNETIC STRATIGRAPHY}

\section{Hole 417D}

Chemical type 417D-A at the top of the hole corresponds exactly to lithologic Sub-unit 1A, a pillowed flow unit with plagioclase and olivine phenocrysts. A thin sedimentary interbed occurs at the base of this unit. This chemical type can be derived from the more magnesian chemical type 417D-B by fractionation. This requires substantial augite which is not a phenocryst phase in this unit. These two chemical types, therefore, must represent two distinct magma batches.
The next chemical type, 417D-B, the most magnesian type in this hole, corresponds to lithologic Sub-units $1 \mathrm{~B}$ and $1 \mathrm{C}$ and Units 2 and 3 . The first three are pillowed flows separated by thin sedimentary interbeds; Unit 3 is a massive flow. Both pillowed and massive flows have plagioclase, olivine, and augite phenocrysts. Most of the chemical variation in this hole could be explained by low-pressure fractionation using this chemical type as the parental liquid.

Chemical type $417 \mathrm{D}-\mathrm{C}$ occurs in the upper part of lithologic Unit 4, a pillowed flow with phenocrysts of plagioclase, olivine, and augite. It can be related to the flows above by a small amount of crystallization. The remainder of lithologic Unit 4 (chemical type 417D-D) cannot be related to any other flows in this hole by fractional crystallization, though it is lithologically similar to them and only slightly different chemically. The base of this unit corresponds to the first magnetic boundary within this hole: a change in inclination considered by the Leg 51 scientists to indicate a fault zone with minor rotation. A small amount of breccia occurs within this zone.

Chemical type 417D-E corresponds to the lithologic Units 5, 6, and 7, which contain phenocrysts of plagioclase, olivine, and augite. They fall on the trend of fractionation from chemical type 417D-B; but because they are separated by $417 \mathrm{D}-\mathrm{D}$ (which does not lie on this trend), 417D-E is a separate magma batch. The lower boundary of this chemical 

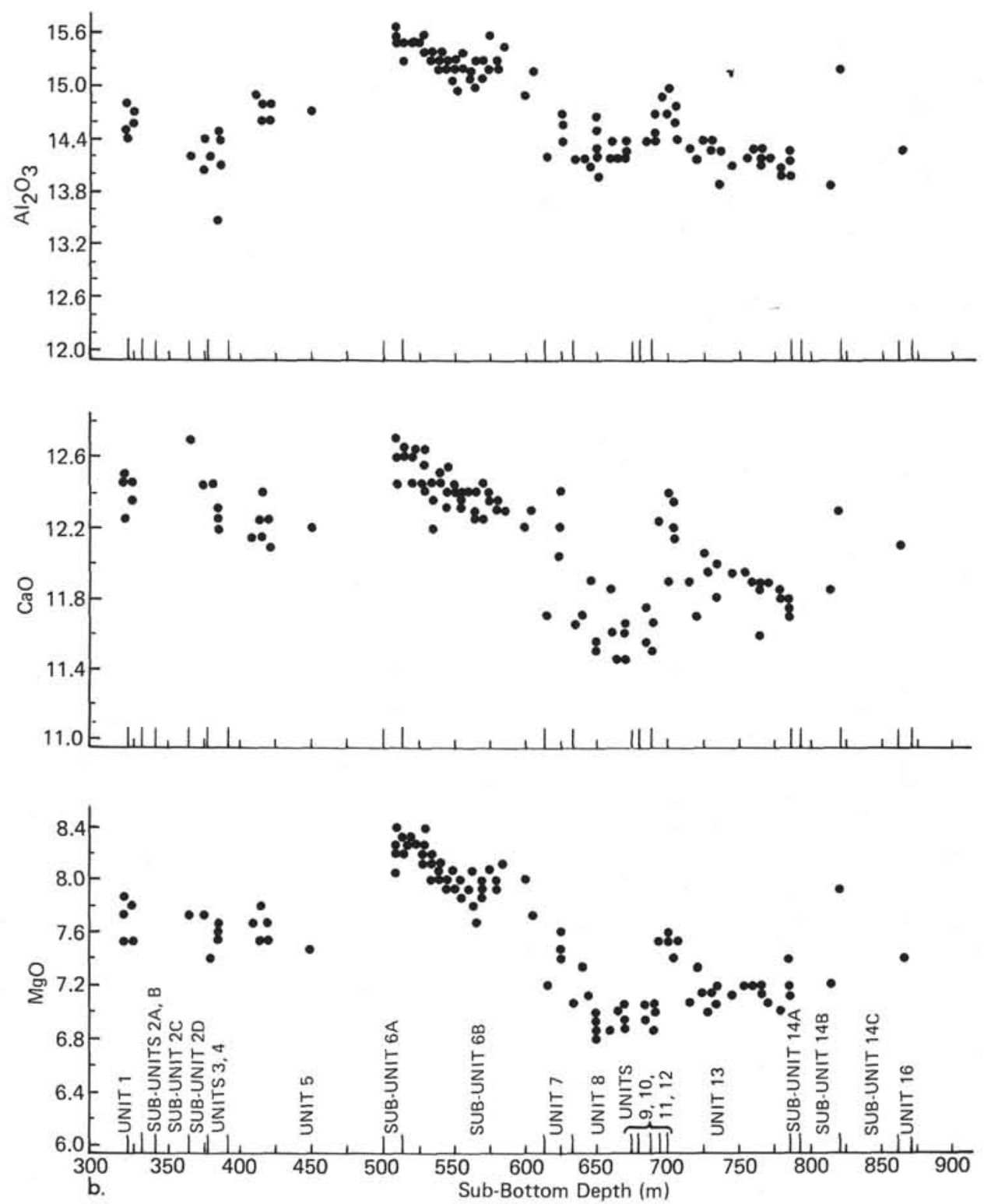

Figure 2. (Continued).

type is poorly constrained because of the lack of recovery in the interval from 501 to 532 meters sub-bottom and because no fresh glass was recovered from the two massive Subunits $8 \mathrm{~A}$ and $8 \mathrm{~B}$.

Chemical type 417D-F occurs in the upper 25 meters of lithologic Sub-unit 9A, a pillowed flow with plagioclase, olivine, and clinopyroxene phenocrysts. It can be related to 417D-E by fractional crystallization so these chemical types may be considered to represent a single magma batch. It also lies on the trend of fractional crystallization from the more magnesian liquid 417D-B. No glass was recovered from the breccias in the lower part of Sub-unit 9A or in 9B. A thin zone of hyaloclastite with fresh glass in lithologic Sub-unit 9C yields chemical type 417D-G, which is unlike any other chemical type in this hole, but similar to that of the fractionation trend from 418A-B.

Chemical type 417D-H corresponds to lithologic Sub-unit 9D and Unit 11 (and possibly Sub-units 10A and 10B). Phenocryst phases are plagioclase and olivine and rare clinopyroxene megacysts. Sub-unit 9D and Unit 11 are pillowed flows; between them are the two massive flows (10A and 10B). Fresh glass was not recovered from the massive flows, and their chemical affinity is unknown. Chemical type 417D-H lies on the 417D-5 fractionation trend but is considered a separate magma batch because of its physical separation. There are several minor changes in magnetic inclination that produce a net change of about $30^{\circ}$ between 650 and 675 meters sub-bottom. These changes do not correlate well with either the chemical or lithologic unit boundaries. The last three lithologic units do not contain fresh glass. Because of differences in phenocryst phases, these units are probably not equal to the units in chemical type $417 \mathrm{D}-\mathrm{H}$ but might be related by fractional crystallization.

\section{Hole 418A}

Chemical type 418A-A includes lithologic Unit 1; Sub-units 2A, 2B, 2C, and 2D; and Units 3 and 4. These are 

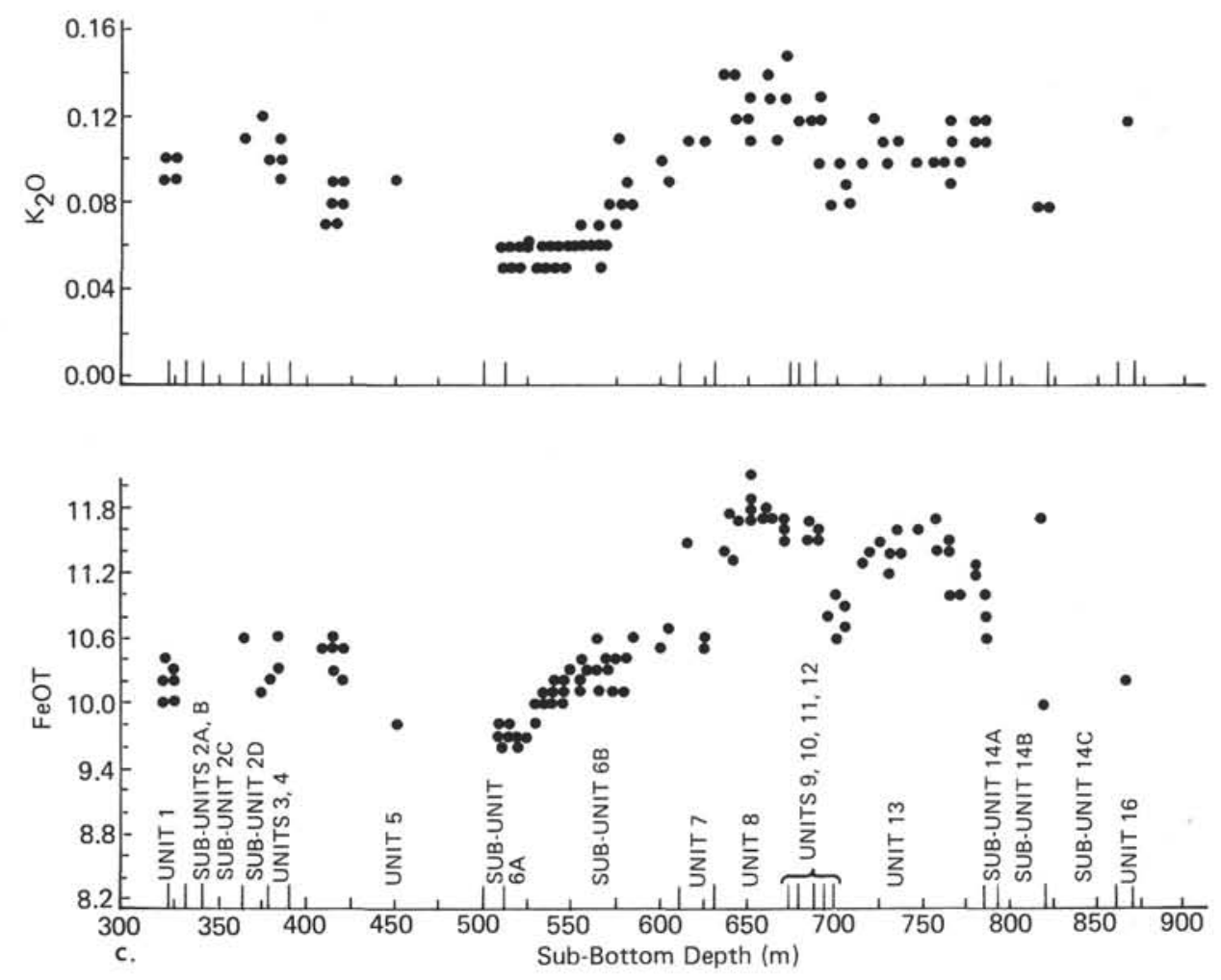

Figure 2. (Continued).

pillowed flows (Units 1 and 3 ) and massive flows (Units 2 and 4) with phenocrysts of plagioclase and olivine. Chemical differences between these units and the ones immediately below are quite minor and may be partially due to several slightly altered samples (VGM $-2928,2930$, and 2935). These glasses have significantly lower $\mathrm{Al}_{2} \mathrm{O}_{3}$ and $\mathrm{Na}_{2} \mathrm{O}$ than surrounding glasses. Two of these samples are from selvages of massive flows and may have been altered during prolonged periods at high temperatures.

Chemical type 418A-B corresponds to the pillowed Unit 5. The phenocryst assemblage is plagioclase and olivine, and the rocks are similar to those above in both lithology and magnetic inclination. These two chemical types, $418 \mathrm{~A}-\mathrm{A}$ and $\mathrm{B}$, along with the glass from the top of Hole 418B differ from most of the other chemical types in either $417 \mathrm{D}$ or $418 \mathrm{~A}$. They can be related to the dike $(418 \mathrm{~A}-\mathrm{L})$ by a small amount of fractional crystallization. This dike is of normal polarity, as are the upper five lithologic units of this hole. No glass occurs in the interval from 452 to 510 meters sub-bottom (Unit 5 and Sub-unit 6A).

The breccia of Sub-unit 6A contains no fresh glass. Subunit $6 \mathrm{~B}$ is divided into chemical types $418 \mathrm{~A}-\mathrm{C}$, D, and $\mathrm{E}$. The breccia of Sub-unit $6 \mathrm{~A}$ and the pillows of $6 \mathrm{~B}$ are distinctive in the common occurrence of spinel in the groundmass and as inclusions in plagioclase and olivine. These units also occur below a magnetic polarity change. Chemical type 418A-C corresponds to the interval from 510 to 530 meters sub-bottom in Sub-unit $6 \mathrm{~B}$ and is the most magnesian composition found in either hole. For this reason, it was chosen as the parental liquid in our initial least-squares models of fractional crystallization. After fractional crystallization is considered, only small differences exist between this chemical type and all others from 417D and 418A. Fractional crystallization models with plagioclase, olivine, and augite can explain all the variation between 418A-C and 418A-D and E, the other two chemical types within Sub-unit 6B. However, this unit does not contain augite as a phenocryst phase. Chemical type 418A-D occurs within the interval from 530 to 567 meters and 418A-E occurs within the interval from 567 to 611 meters sub-bottom (ending at the base of lithologic Sub-unit 6B). The compositional variation between 418A-D and $\mathrm{E}$ is quite minor and statistically just significant. Because of the similarities in chemistry, lithology, and magnetic inclinations between these three chemical types of lithologic Subunit $6 \mathrm{~B}$, they could possibly represent one complex eruptive event which becomes slightly more magnesian during the eruption. This could represent a zoned magma chamber or mixing of newly arrived, unfractionated magma with previously fractionated magma.

In contrast to the above units, lithologic Unit 7 contains augite along with plagioclase and olivine as phenocryst phases. The upper part of this pillowed unit is chemical type $418 \mathrm{~A}-\mathrm{F}$, while the lower part is $418 \mathrm{~A}-\mathrm{G}$. Fractional crystallization adequately explains the differences between these two chemical types. The stratigraphic interval of chemical type 418A-G represents a short duration magnetic reversal.

Pillowed Sub-unit $8 \mathrm{C}$ and Unit 11 comprise chemical type $418 \mathrm{~A}-\mathrm{H}$. Augite continues to be an abundant phenocryst along with plagioclase and olivine. This chemical type can be derived from 418A-G by fractional crystallization. No glass was obtained from the massive Sub-unit $8 \mathrm{~B}$ or Units 9 and 10. The two massive flows (9 and 10) do not contain augite and probably represent a different magma. A 
change in magnetic inclination occurs at the base of chemical type $418 \mathrm{~A}-\mathrm{H}$.

Chemical type $418 \mathrm{~A}-\mathrm{I}$ is found in the upper 10 meters of lithologic Unit 13. Similar to the rocks above it, this unit contains phenocrysts of plagioclase, olivine, and augite and has a composition similar to $418 \mathrm{~A}-\mathrm{G}$. A slight change in magnetic inclination marks the lower boundary of this chemical type within Unit 13. Chemical type 418A-J occurs in the remainder of Unit 13. It can also be related to the 418A-G chemical type by fractional crystallization. A minor inclination change occurs within 418A-J and one occurs at the boundary between Unit 13 and Sub-unit 14A.

Chemical type $418 \mathrm{~A}-\mathrm{K}$ is a single analysis from the upper glassy selvage of the massive flow Sub-unit 14A. This sub-unit has phenocrysts of plagioclase, olivine, and augite and can be related to the above units by fractional crystallization from chemical type 418A-G.

Lithologic Sub-unit $15 \mathrm{~A}$ is a dike within the massive Sub-unit 14B. The dike has phenocrysts of plagioclase, olivine, and augite. The analysis of its glassy selvage represents chemical type $418 \mathrm{~A}-\mathrm{L}$. This may be related by fractional crystallization to the flows at the top of this hole (chemical type 418A-B); it has normal polarity as do the upper flows.

Chemical type $418 \mathrm{~A}-\mathrm{M}$ is a single analysis from the upper glassy selvage of the massive flow Sub-unit $14 \mathrm{C}$. This flow contains plagioclase and rare olivine and augite phenocrysts. Its composition is quite magnesian and is similar to chemical types $418 \mathrm{~A}-\mathrm{C}, \mathrm{D}$ and $\mathrm{E}$.

The lowest unit in this hole is 16 , a pillowed flow with phenocrysts of plagioclase, olivine, and rare clinopyroxene. One analysis from this unit yields chemical type 418A-N.

\section{GLASS INCLUSIONS IN PLAGIOCLASE PHENOCRYSTS}

Glass inclusions are very common in the plagioclase phenocrysts from both holes. These inclusions are commonly devitrified, but fresh glass and vapor inclusions are preserved in the fresh margins of pillows. Inclusions range in size from about 10 to 100 microns in diameter. Major element analyses were made on inclusions using the same standards and operating conditions as used for analyses of the glassy selvages, except where the diameter of the beam was necessarily reduced to eliminate effects of the host grain on the analyses of the smaller inclusions. The glass selvages surrounding the host plagioclase were then re-analyzed with the smaller diameter beam to check for any bias produced by this change. No differences were observed in the analyses of the selvages using 50-micron and 10-micron beam diameters.

Inclusion compositions are presented in Table 5. At this time, we present only a preliminary discussion of the data. Plots of these data on $\mathrm{MgO}$ variation diagrams yield fairly well defined trends for the data as a whole and still better trends when only inclusions from single chemical types are plotted together. Compared to the trends found in the data from glassy selvages, the inclusions tend to conform to an extension of this trend to more magnesian compositions (to about $10.5 \% \mathrm{MgO}$ ). The major exception to this is in $\mathrm{Al}_{2} \mathrm{O}_{3}$ which remains remarkably constant with increasing $\mathrm{MgO}$ in the inclusions. This may indicate an important change in the liquid line of descent or possibly may be related to crystallization of plagioclase on the walls of the host.

Although relatively coherent trends exist for many of these analyzed inclusions, models based on fractional crystallization cannot explain these chemical trends. Even the addition of orthopyroxene fails to account for the chemical variation. The basic problem in all cases is that $\mathrm{TiO}_{2}$ is too low in the inclusions, and (unless orthopyroxene is used) $\mathrm{SiO}_{2}$ is too high in the inclusions, compared to the solutions obtained from least-squares fractionation models. If $\mathrm{TiO}_{2}$ is forced to fit by weighting the solutions, then high positive residuals result for $\mathrm{FeO}$ and $\mathrm{Na}_{2} \mathrm{O}$ and negative ones for $\mathrm{MgO}$ and $\mathrm{Al}_{2} \mathrm{O}_{3}$.

In a simple fractionating liquid, the inclusions should all lie on a liquid line of descent controlled by simple removal of crystal phases, but this relationship could be altered by several factors. (1) Crystallization of the host phase would move the glass inclusions off the liquid line of descent (Watson, 1976). (2) Diffusion gradients at the growing crystal surface (Lofgren, 1974) might produce liquid inclusions which would not be representative of the host liquid. (3) Magma mixing or contamination after the onset of crystallization could alter the liquid line of descent in such a way that crystal-liquid fractionation models would not explain the observed variation in glass inclusions (Dungan et al., 1977). (4) Growth of a daughter crystal within the inclusion (Roedder and Weiblen, 1971) would cause a departure from the liquid line of descent. (5) Eruption of liquids from a zone undergoing continuous partial melting would result in a coherent liquid trend not controlled by removal of crystal phases (Wright and Helz, 1976).

Until we have more analyses, especially multiple analyses from single grains, single thin sections, and single units to determine the variation at these levels, we will only use these data to suggest several points about the liquid line of descent. The very low concentrations of $\mathrm{K}_{2} \mathrm{O}, \mathrm{TiO}_{2}$, and $\mathrm{P}_{2} \mathrm{O}_{5}$ in these inclusions require that they represent much more primitive liquids than any observed in the basalts from Holes 417D and 418A, and more primitive than any previously reported for glassy selvages from mid-ocean spreading centers (if only $\mathrm{TiO}_{2}$ is considered). These concentrations suggest that the $417 \mathrm{D}$ and $418 \mathrm{~A}$ basalts are already highly fractionated, representing 50 to 75 per cent crystallization from an earlier basaltic liquid. Our inability to model fractionation successfully must result from one of the above-mentioned factors though it seems most likely that the trends found for the glass inclusions reflect fractionation of a high-pressure pyroxene (increased $\mathrm{Na}_{2} \mathrm{O}$ and $\mathrm{Al}_{2} \mathrm{O}_{3}$ ), magma mixing, or continuous partial melting and eruptions.

\section{COMPARISON OF GLASS AND WHOLE-ROCK ANALYSES}

The importance of glasses in the study of ocean-floor basalts has been discussed in several papers (Melson, 1973, 1979; Frey et al., 1974; Melson et al., 1976; and Byerly et al., 1977). There are two important differences between compositions obtained from microprobe analysis of natural glasses and compositions obtained by other methods on whole-rock samples. Many studies have shown that whole- 
TABLE 2

Average Composition and Standard Deviation of Chemical Types Based on Two or More Samples; Norms Assume $\mathrm{Fe}_{2} \mathrm{O}_{3}=15 \% \mathrm{FeOT}$

\begin{tabular}{|c|c|c|c|c|c|c|c|c|}
\hline Chemical Type & 417D-A & 417D-B & $417 \mathrm{D}-\mathrm{C}$ & 417D-D & 417D-E & $417 \mathrm{D}-\mathrm{F}$ & 417D-H & 418A-A \\
\hline Symbol & 1 & 2 & 3 & 4 & 5 & 6 & 8 & A \\
\hline Analyses & 10 & 19 & 15 & 2 & 7 & 10 & 15 & 12 \\
\hline $\mathrm{SiO}_{2}$ & $50.46 \pm 0.30$ & $50.70 \pm 0.25$ & $50.71 \pm 0.41$ & $50.60 \pm 0.25$ & $50.70 \pm 0.23$ & $50.64 \pm 0.33$ & $50.72 \pm 0.34$ & $51.15 \pm 0.41$ \\
\hline $\mathrm{Al}_{2} \mathrm{O}_{3}$ & $14.46 \pm 0.16$ & $14.59 \pm 0.19$ & $14.32 \pm 0.17$ & $14.28 \pm 0.20$ & $14.04 \pm 0.16$ & $13.95 \pm 0.14$ & $14.32 \pm 0.12$ & $14.36 \pm 0.34$ \\
\hline FeOT & $11.27 \pm 0.26$ & $11.28 \pm 0.18$ & $11.61 \pm 0.12$ & $11.10 \pm 0.01$ & $11.74 \pm 0.07$ & $11.97 \pm 0.18$ & $11.58 \pm 0.19$ & $10.31 \pm 0.19$ \\
\hline $\mathrm{MgO}$ & $7.20 \pm 0.11$ & $7.46 \pm 0.19$ & $7.14 \pm 0.11$ & $7.30 \pm 0.13$ & $7.04 \pm 0.10$ & $6.84 \pm 0.15$ & $7.13 \pm 0.14$ & $7.67 \pm 0.14$ \\
\hline $\mathrm{CaO}$ & $11.73 \pm 0.11$ & $11.86 \pm 0.10$ & $11.81 \pm 0.10$ & $12.08 \pm 0.15$ & $11.81 \pm 0.06$ & $11.61 \pm 0.08$ & $11.64 \pm 0.09$ & $12.39 \pm 0.14$ \\
\hline $\mathrm{Na}_{2} \mathrm{O}$ & $2.33 \pm 0.04$ & $2.28 \pm 0.05$ & $2.31 \pm 0.04$ & $2.27 \pm 0.03$ & $2.34 \pm 0.01$ & $2.36 \pm 0.03$ & $2.34 \pm 0.02$ & $2.21 \pm 0.11$ \\
\hline $\mathrm{K}_{2} \mathrm{O}$ & $0.10 \pm 0.02$ & $0.09 \pm 0.01$ & $0.10 \pm 0.01$ & $0.09 \pm 0.00$ & $0.10 \pm 0.01$ & $0.08 \pm 0.01$ & $0.09 \pm 0.01$ & $0.10 \pm 0.01$ \\
\hline $\mathrm{TiO}_{2}$ & $1.59 \pm 0.04$ & $1.53 \pm 0.04$ & $1.64 \pm 0.04$ & $1.50 \pm 0.04$ & $1.69 \pm 0.03$ & $1.80 \pm 0.04$ & $1.62 \pm 0.04$ & $1.26 \pm 0.04$ \\
\hline $\mathrm{P}_{2} \mathrm{O}_{5}$ & $0.14 \pm 0.01$ & $0.13 \pm 0.01$ & $0.14 \pm 0.02$ & $0.14 \pm 0.01$ & $0.14 \pm 0.02$ & $0.15 \pm 0.01$ & $0.14 \pm 0.01$ & $0.11 \pm 0.01$ \\
\hline Total & 99.28 & 99.93 & 99.79 & 99.35 & 99.61 & 99.38 & 99.60 & 99.56 \\
\hline Qz & 1.05 & 0.89 & 1.29 & 1.15 & 1.42 & 1.83 & 1.39 & 1.31 \\
\hline Or & 0.60 & 0.53 & 0.59 & 0.54 & 0.59 & 0.48 & 0.53 & 0.59 \\
\hline $\mathrm{Ab}$ & 19.86 & 19.31 & 19.59 & 19.34 & 19.88 & 20.09 & 19.89 & 18.79 \\
\hline An & 28.92 & 29.35 & 28.48 & 28.71 & 27.63 & 27.41 & 28.44 & 29.11 \\
\hline $\mathrm{Di}$ & 14.20 & 14.29 & 14.26 & 15.23 & 14.61 & 14.05 & 13.92 & 16.46 \\
\hline $\mathrm{Hd}$ & 9.39 & 9.20 & 9.80 & 9.86 & 10.24 & 10.25 & 9.58 & 9.59 \\
\hline En & 11.44 & 11.92 & 11.16 & 11.19 & 10.78 & 10.58 & 11.33 & 11.51 \\
\hline Fs & 8.69 & 8.82 & 8.81 & 8.33 & 8.69 & 8.88 & 8.96 & 7.71 \\
\hline Fo & - & - & - & - & - & - & - & - \\
\hline $\mathrm{Fa}$ & - & - & - & - & - & - & - & - \\
\hline $\mathrm{Mg}$ & 2.48 & 2.46 & 2.54 & 2.44 & 2.57 & 2.63 & 2.54 & 2.26 \\
\hline Il & 3.05 & 2.92 & 3.13 & 2.88 & 3.25 & 3.45 & 3.08 & 2.41 \\
\hline Ap & 0.33 & 0.31 & 0.33 & 0.33 & 0.33 & 0.36 & 0.33 & 0.26 \\
\hline
\end{tabular}

rock analyses often reflect the ubiquitous presence of secondary alteration products in ocean-floor rocks. Most ocean-floor rocks contain carbonate, silica, and smectites in veins and vesicles, even when the primary minerals in the rocks are unaltered. Natural glasses, on the other hand, are often completely free of secondary alteration, and even substantially altered rocks may contain small volumes of fresh glass which can be analyzed by microprobe. Secondly, glasses represent the magmatic liquids at the time they are quenched during extrusion onto the ocean floor. In a detailed study of rock and glass compositions at DSDP Site 332 , Byerly and Wright (1978) found that many rocks do not lie on the liquid line of descent for the magmas producing oceanic crust. The rocks commonly reflect accumulation of one or more phenocryst phases in proportions differing from the proportions crystallizing.

Substantial differences exist between much of the glass chemistry for these two holes and the partial whole-rock analyses reported in the Site Reports, Sites 417 and 418 (this volume). These differences potentially reflect three effects: (1) analytical biases, (2) crystallization and redistribution of phenocrysts, and (3) alteration. Because both data sets were generated using inter-laboratory standards of ocean-floor basalt composition, it is likely that biases (though they probably do exist) are relatively small compared to the second and third aforementioned effects.

Because data on $\mathrm{Na}_{2} \mathrm{O}$ were not available for the shipboard samples, we have not attempted to test quantitatively any models for phenocryst accumulation. However, for the available oxides, plots of whole-rock versus glass composition for single units clearly show that the rocks do not lie on the liquid line of descent, but generally fall off in the direction required by accumulation of plagioclase. All of the fractionation calculations based on glass compositions clearly indicate the dominant effect of plagioclase crystallization in producing the liquid line of descent in these glasses. Since the density of anorthitic plagioclase is close to that of basaltic liquids, in contrast to the higher densities of olivine and clinopyroxene, it is not surprising that such relationships might exist. Indeed, if plagioclase is lighter than the basaltic liquids, we might even see accumulation of plagioclase by flotation to the top of magma chambers prior to eruption (Bryan and Moore, 1977).

Finally, clear evidence of alteration in these rocks is presented in the lithologic descriptions for most units (see Site Reports, Sites 417 and 418 , this volume). We have not attempted to make quantitative comparisons between potential models for alteration using glass data versus whole-rock data for single units. However, such tests are needed and can yield important results in attempting to understand the mechanisms of alteration, the geochemical fluxes involved in the alteration of the basalt pile, and the hazards involved in using chemical data on altered basalts for petrogenetic studies.

\section{YOUNGER MORB GLASSES AND VARIATIONS ALONG THE MAR}

Major element analyses of natural glasses are available from many segments of the ocean spreading centers. The 
TABLE 2 - Continued

\begin{tabular}{|c|c|c|c|c|c|c|c|c|}
\hline Chemical Type & $418 \mathrm{~A}-\mathrm{B}$ & $418 \mathrm{~A}-\mathrm{C}$ & 418A-D & $418 \mathrm{~A}-\mathrm{E}$ & $418 \mathrm{~A}-\mathrm{G}$ & $418 \mathrm{~A}-\mathrm{H}$ & $418 \mathrm{~A}-\mathrm{I}$ & 418A-J \\
\hline Symbol & B & $\mathrm{C}$ & D & $\mathrm{E}$ & G & $\mathrm{H}$ & I & J \\
\hline Analyses & 7 & 11 & 20 & 10 & 3 & 19 & 6 & 18 \\
\hline $\mathrm{SiO}_{2}$ & $51.00 \pm 0.28$ & $50.27 \pm 0.33$ & $50.13 \pm 0.25$ & $50.45 \pm 0.38$ & $50.83 \pm 0.37$ & $50.60 \pm 0.35$ & $50.84 \pm 0.65$ & $51.03 \pm 0.35$ \\
\hline $\mathrm{Al}_{2} \mathrm{O}_{3}$ & $14.72 \pm 0.11$ & $15.50 \pm 0.11$ & $15.28 \pm 0.12$ & $15.25 \pm 0.19$ & $14.55 \pm 0.13$ & $14.32 \pm 0.18$ & $14.73 \pm 0.20$ & $14.19 \pm 0.14$ \\
\hline $\mathrm{FeOT}$ & $10.33 \pm 0.25$ & $9.71 \pm 0.07$ & $10.17 \pm 0.16$ & $10.37 \pm 0.19$ & $10.59 \pm 0.06$ & $11.65 \pm 0.19$ & $10.76 \pm 0.14$ & $11.31 \pm 0.24$ \\
\hline $\mathrm{MgO}$ & $7.60 \pm 0.13$ & $8.28 \pm 0.09$ & $8.00 \pm 0.13$ & $7.97 \pm 0.12$ & $7.49 \pm 0.12$ & $6.98 \pm 0.12$ & $7.49 \pm 0.08$ & $7.13 \pm 0.09$ \\
\hline $\mathrm{CaO}$ & $12.21 \pm 0.09$ & $12.60 \pm 0.08$ & $12.40 \pm 0.09$ & $12.34 \pm 0.08$ & $12.22 \pm 0.16$ & $11.62 \pm 0.12$ & $12.20 \pm 0.17$ & $11.86 \pm 0.11$ \\
\hline $\mathrm{Na}_{2} \mathrm{O}$ & $2.26 \pm 0.04$ & $2.21 \pm 0.03$ & $2.24 \pm 0.03$ & $2.26 \pm 0.07$ & $2.32 \pm 0.06$ & $2.42 \pm 0.04$ & $2.36 \pm 0.04$ & $2.34 \pm 0.04$ \\
\hline $\mathrm{K}_{2} \mathrm{O}$ & $0.08 \pm 0.01$ & $0.06 \pm 0.00$ & $0.06 \pm 0.01$ & $0.08 \pm 0.01$ & $0.11 \pm 0.00$ & $0.12 \pm 0.01$ & $0.09 \pm 0.01$ & $0.11 \pm 0.01$ \\
\hline $\mathrm{TiO}_{2}$ & $1.33 \pm 0.03$ & $1.13 \pm 0.02$ & $1.24 \pm 0.03$ & $1.23 \pm 0.03$ & $1.38 \pm 0.01$ & $1.67 \pm 0.06$ & $1.37 \pm 0.04$ & $1.54 \pm 0.03$ \\
\hline $\mathrm{P}_{2} \mathrm{O}_{5}$ & $0.11 \pm 0.02$ & $0.10 \pm 0.01$ & $0.11 \pm 0.01$ & $0.11 \pm 0.01$ & $0.13 \pm 0.00$ & $0.14 \pm 0.02$ & $0.13 \pm 0.01$ & $0.14 \pm 0.01$ \\
\hline Total & 99.65 & 99.86 & 99.61 & 100.07 & 99.63 & 99.53 & 99.98 & 99.66 \\
\hline $\mathrm{Qz}$ & 1.10 & - & - & - & 0.70 & 1.03 & 0.37 & 1.60 \\
\hline Or & 0.47 & 0.30 & 0.36 & 0.47 & 0.65 & 0.71 & 0.53 & 0.65 \\
\hline $\mathrm{Ab}$ & 19.20 & 18.74 & 19.03 & 19.12 & 19.71 & 20.58 & 19.98 & 19.88 \\
\hline An & 29.91 & 32.29 & 31.59 & 31.23 & 29.09 & 28.00 & 29.35 & 28.00 \\
\hline $\mathrm{Di}$ & 15.55 & 15.95 & 15.46 & 15.22 & 15.73 & 13.99 & 15.33 & 14.75 \\
\hline Hd & 9.08 & 8.17 & 8.52 & 8.63 & 9.54 & 9.83 & 9.48 & 9.95 \\
\hline En & 11.74 & 11.03 & 11.19 & 11.49 & 11.39 & 10.94 & 11.51 & 10.94 \\
\hline Fs & 7.88 & 6.50 & 7.09 & 7.49 & 7.93 & 8.83 & 8.18 & 8.48 \\
\hline Fo & - & 1.52 & 1.11 & 0.87 & - & - & - & - \\
\hline $\mathrm{Fa}$ & - & 0.99 & 0.78 & 0.62 & - & - & - & - \\
\hline $\mathrm{Mg}$ & 2.26 & 2.12 & 2.23 & 2.26 & 2.32 & 2.55 & 2.35 & 2.48 \\
\hline Il & 2.54 & 2.16 & 2.37 & 2.34 & 2.64 & 3.20 & 2.61 & 2.94 \\
\hline Ap & 0.26 & 0.24 & 0.26 & 0.26 & 0.31 & 0.33 & 0.31 & 0.33 \\
\hline
\end{tabular}

North Atlantic is perhaps the best sampled region, at least north of about $20^{\circ} \mathrm{N}$. The data of Melson et al. (1976), Bryan and Moore (1977), Byerly and Wright (1978), and Melson (1979) provide an important source of comparison to the much older glasses of DSDP Holes 417D and 418A. Two questions can be considered. First, are there secular changes in the nature of the basalts generated at the Mid-Atlantic Ridge: clear differences in the major element compositions of $417 \mathrm{D}-418 \mathrm{~A}$ basalts as compared to the much younger basalts of the Mid-Atlantic Ridge? Second, if the compositions are similar to modern basalts, can they be related to any specific section of the modern Mid-Atlantic Ridge, which shows distinctive gradations in the composition of erupted basalts along its length (Melson et al., 1976)?

Secular changes in composition were noted for the basalts of DSDP Leg 37. A comparison of rocks collected along a simple spreading line from the FAMOUS area within the median valley, to progressively older basalts at DSDP Sites $332,333,334$, and 335 , demonstrated significant changes in the ratio of light to heavy rare earth elements (Schilling et al., 1977). However, these changes are well within the range commonly found for mid-ocean ridge basalts, as are the major element compositions (Bryan and Moore, 1977; Byerly and Wright, 1978). Schilling et al. (1977) ascribe the differences found to variations in the influence of the Azores hot spot with time.

The glasses from DSDP Sites 417 and 418 fall within the range of compositions of modern ocean spreading center glasses found in the study of Melson et al. (1976), as do glasses from other old DSDP sites. This would suggest that, as a group, there has been no secular variation in mid-ocean spreading center basalts in the past 100 million years. However, when the Site 417/418 glasses are compared to those recovered from the modern Mid-Atlantic Ridge at $22^{\circ} \mathrm{N}$ (approximately on the same spreading line), we find very significant differences in major element compositions. The most significant differences are higher $\mathrm{CaO}$ and lower $\mathrm{Na}_{2} \mathrm{O}$ (at constant $\mathrm{MgO}$ ) for the Site 417/418 glasses. Generalized trends for the chemical variation at $22^{\circ} \mathrm{N}$ and $37^{\circ} \mathrm{N}$ on the Mid-Atlantic Ridge are plotted on Figure 3 for comparison with the Site $417 / 418$ data. Though differing from both groups, the Site 417/418 glasses seem more like those from $37^{\circ} \mathrm{N}$.

There is a very pronounced gradient from high $\mathrm{CaO}$ and low $\mathrm{Na}_{2} \mathrm{O}$ in the region north of $30^{\circ} \mathrm{N}$, to lower $\mathrm{CaO}$ and higher $\mathrm{Na}_{2} \mathrm{O}$ towards the equator (comparisons at constant $\mathrm{MgO}$ ). These differences may not be related simply to low-pressure fractional crystallization, but may indicate the importance of Ca-rich pyroxene in partial melting and high-pressure fractionation and the possibility that two substantially different mantle mineralogies may be required to generate these two types of basalt (Byerly and Wright, 1978).

These chemical gradients suggested for the Mid-Atlantic Ridge also correlate with geophysical and tectonic patterns. Anderson et al. (1973) have suggested that the long wavelength free-air gravity anomalies of the world's ocean basins cannot be supported by the thickness of the oceanic litho- 


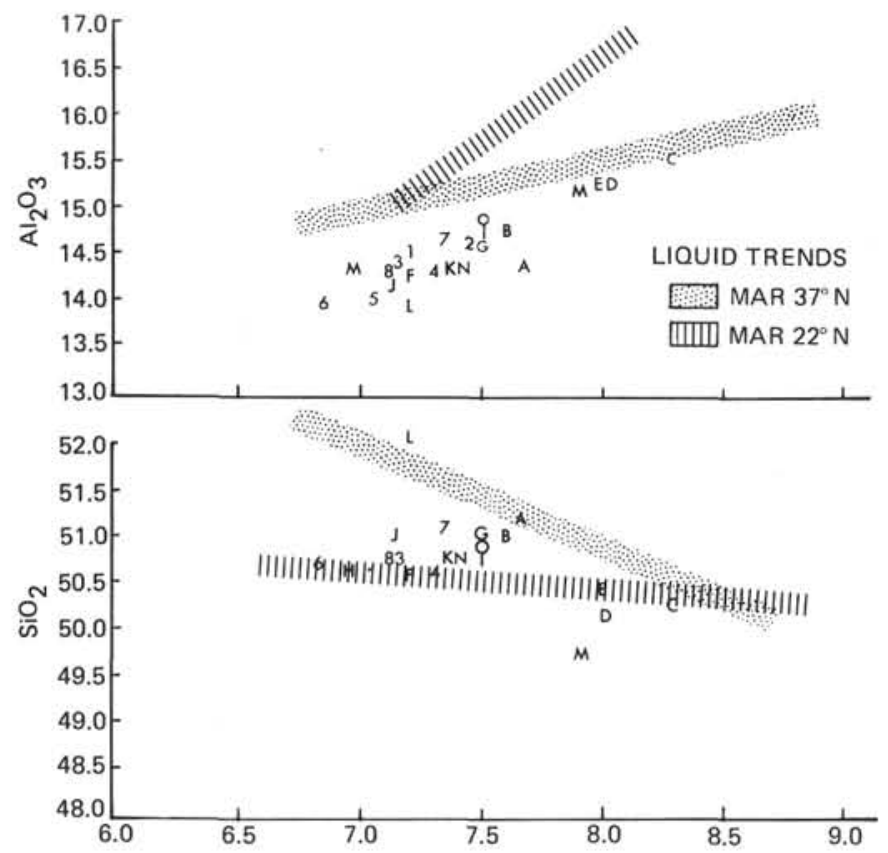

a.
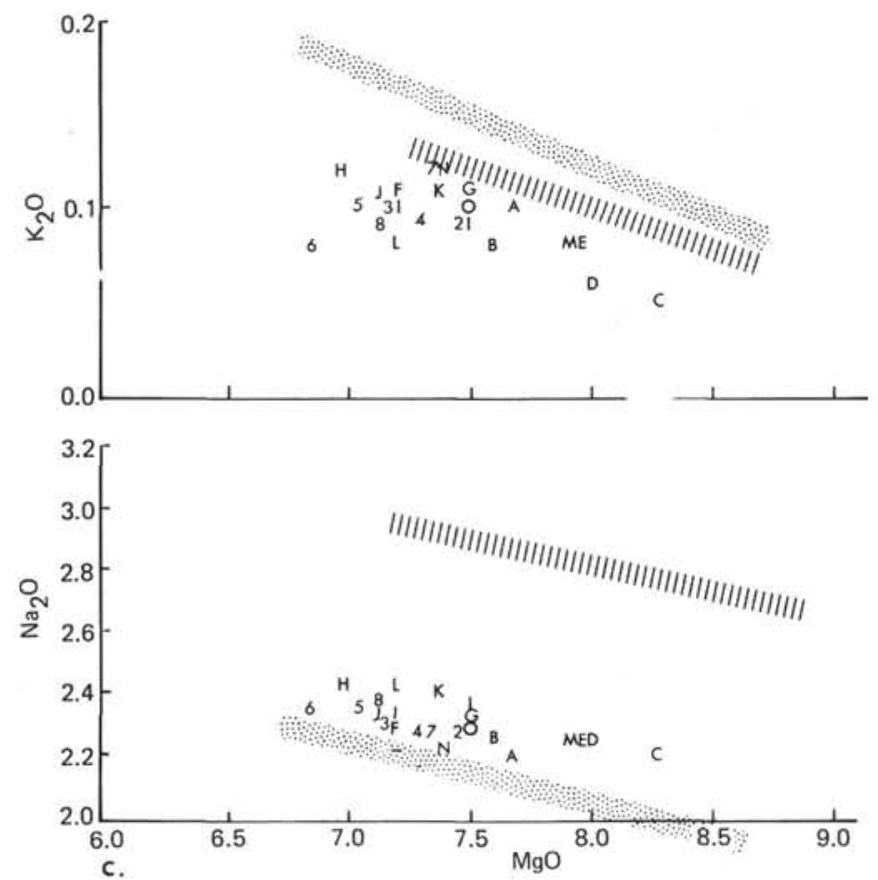
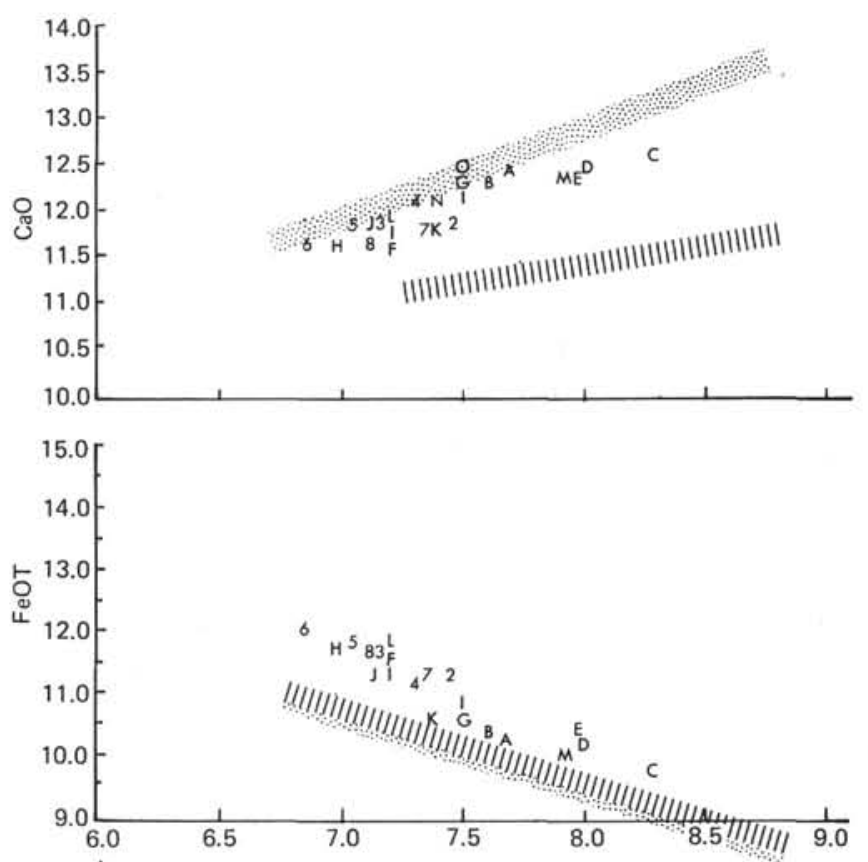

b.
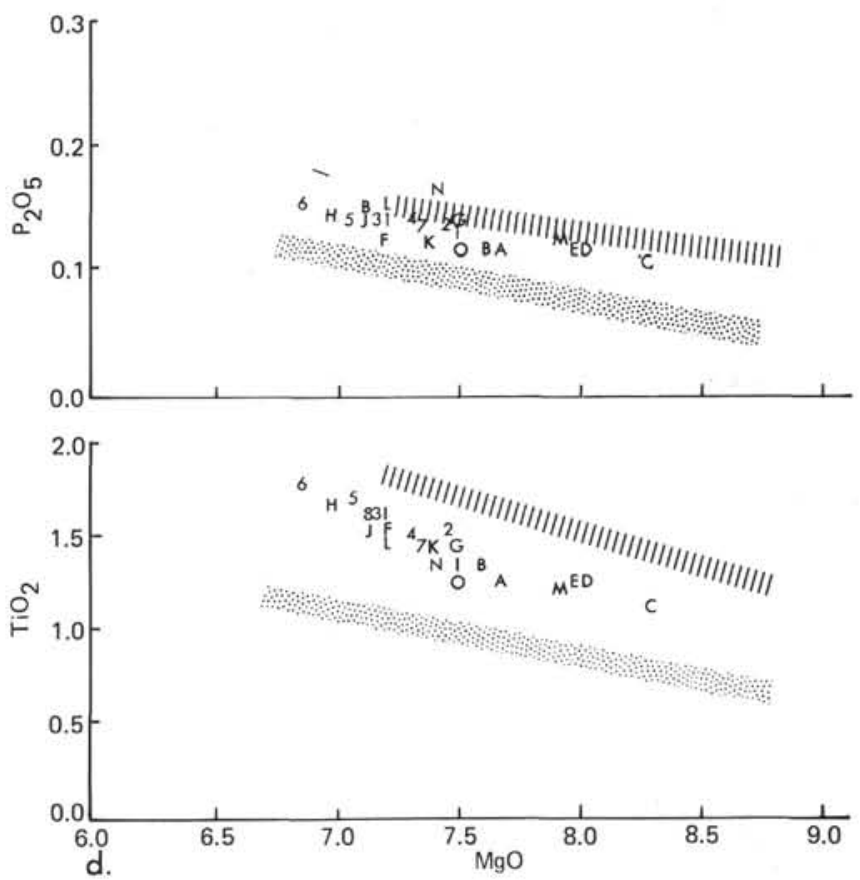

Figure 3. ( $a, b, c, d) \mathrm{MgO}$ variation diagrams for chemical type averages as defined in text (see Table 2). Trends for $37^{\circ} \mathrm{N}$, Mid-Atlantic Ridge, are from Byerly and Wright (in press, Site 332). Trends for $22^{\circ} \mathrm{N}$, Mid-Atlantic Ridge, are from Melson et al. (1976).

sphere, but must represent large areas of asthenospheric upwelling. One of the major anomalies is centered at about $45^{\circ} \mathrm{N}$ on the Mid-Atlantic Ridge and extends towards the equator to about $30^{\circ} \mathrm{N}$ (for $+10 \mathrm{mgal}$ or greater) and north at least to Spitsbergen at $80^{\circ} \mathrm{N}$. This may also be related to the bathymetric relationships between these two areas with generally higher ridges associated with the gravity high. The possible tectonic differences between these two regions may be reflected in the nature of the ridge segments and transform fracture zones. The low-gravity region is characterized by longer transforms and shorter ridge segments while the highgravity region is characterized by shorter transforms and longer ridge segments.

Much more chemical data are needed from the equatorial Atlantic; but, if this correlation between chemistry and gravity holds for the recent Mid-Atlantic Ridge, it suggests that 
TABLE 3

418A-C as a Parental Liquid to All Chemical Types

\begin{tabular}{|c|c|c|c|c|c|}
\hline Chemical Type & $\% \mathrm{Xt1}$ & $\% \mathrm{Pl}$ & $\% 01$ & $\% \mathrm{Cpx}$ & Comments on Residuals and Phenocrysts Observed \\
\hline \multicolumn{6}{|l|}{ Hole 417D } \\
\hline$-\mathrm{A}$ & 30.4 & 16.1 & 4.2 & 10.1 & $\mathrm{Na}_{2} \mathrm{O}=0.09$, no augite in rocks \\
\hline$-B$ & 28.3 & 15.2 & 3.6 & 9.5 & $\mathrm{Na}_{2} \mathrm{O}=0.11$ \\
\hline$-\mathrm{C}$ & 33.8 & 18.2 & 4.7 & 10.9 & $\mathrm{Na}_{2}^{2} \mathrm{O}=0.09$ \\
\hline$-D$ & 28.3 & 15.8 & 4.5 & 8.0 & $\mathrm{Na}_{2}^{2} \mathrm{O}=0.09$ \\
\hline$-\mathrm{E}$ & 36.0 & 19.7 & 5.2 & 11.1 & $\mathrm{Na}_{2} \mathrm{O}=0.07$ \\
\hline$-F$ & 38.6 & 20.9 & 5.4 & 12.3 & $\mathrm{Na}_{2} \mathrm{O}=0.08$ \\
\hline$-\mathrm{G}$ & 28.3 & 14.8 & 3.9 & 9.6 & $\mathrm{Na}_{2} \mathrm{O}=0.20, \mathrm{~K}_{2} \mathrm{O}=-0.04, \mathrm{TiO}_{2}=0.06$ \\
\hline$-\mathrm{H}$ & 33.2 & 17.7 & 4.5 & 11.0 & $\mathrm{Na}_{2} \mathrm{O}=0.11$, rare augite in rocks \\
\hline \multicolumn{6}{|l|}{ Hole 418A } \\
\hline$-\mathrm{A}$ & 16.7 & 10.3 & 4.0 & 2.4 & $\mathrm{Na}_{2} \mathrm{O}=0.19, \mathrm{~K}_{2} \mathrm{O}=-0.03, \mathrm{TiO}_{2}=0.07$, rare augite in rocks \\
\hline$-\mathrm{B}$ & 18.4 & 10.1 & 3.6 & 4.7 & $\mathrm{Na}_{2} \mathrm{O}=0.16$, rare augite in rocks \\
\hline$-\mathrm{D}$ & 9.3 & 4.9 & 1.1 & 3.3 & Rare augite in rocks \\
\hline$-\mathrm{E}$ & 9.6 & 5.1 & 1.0 & 3.5 & Rare augite in rocks \\
\hline$-F$ & 32.2 & 17.4 & 4.5 & 10.3 & $\mathrm{Na}_{2} \mathrm{O}=0.11, \mathrm{~K}_{2} \mathrm{O}=-0.03$ \\
\hline$-\mathrm{G}$ & 21.4 & 12.0 & 3.9 & 5.5 & $\mathrm{Na}_{2} \mathrm{O}=0.08, \mathrm{~K}_{2} \mathrm{O}=-0.04$ \\
\hline$-\mathrm{H}$ & 34.6 & 18.3 & 4.7 & 11.6 & $\mathrm{Na}_{2} \mathrm{O}=0.06, \mathrm{~K}_{2} \mathrm{O}=-0.03$ \\
\hline$-\mathrm{I}$ & 19.9 & 10.9 & 3.3 & 5.7 & \\
\hline$-\mathrm{J}$ & 31.3 & 17.1 & 5.0 & 9.2 & $\mathrm{Na}_{2} \mathrm{O}=0.13, \mathrm{~K}_{2} \mathrm{O}=-0.03$ \\
\hline$-\mathrm{K}$ & 23.2 & 12.5 & 3.9 & 6.8 & $\mathrm{Na}_{2} \mathrm{O}=0.15, \mathrm{~K}_{2} \mathrm{O}=-0.03$ \\
\hline$-\mathrm{L}$ & 32.3 & 18.2 & 5.3 & 8.8 & $\mathrm{Na}_{2} \mathrm{O}=0.18, \mathrm{TiO}_{2}=0.06$ \\
\hline$-\mathrm{M}$ & 9.1 & 4.7 & 1.2 & 3.2 & No augite in rocks \\
\hline$-\mathrm{N}$ & 19.9 & 11.3 & 4.5 & 4.1 & $\mathrm{Na}_{2} \mathrm{O}=0.21, \mathrm{~K}_{2} \mathrm{O}=-0.05$ \\
\hline \multicolumn{6}{|l|}{ Hole 418B } \\
\hline-0 & 14.9 & 8.3 & 3.9 & 2.7 & $\mathrm{Na}_{2} \mathrm{O}=0.14, \mathrm{~K}_{2} \mathrm{O}=-0.03$ \\
\hline
\end{tabular}

TABLE 4

Magma Batch Stratigraphy ${ }^{\mathrm{a}}$

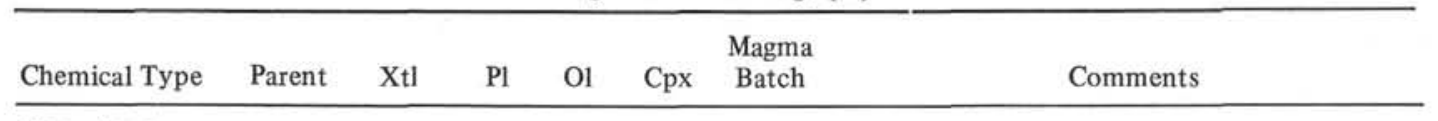

Hole 417D-

$\begin{array}{lcllllll}-\mathrm{A} & - & & & & & \text { I } & \text { Similar to 417D-C, but no augite } \\ -\mathrm{B} & - & & & & & \text { II } & \\ -\mathrm{C} & 417 \mathrm{D}-\mathrm{B} & 6.1 & 3.5 & 1.2 & 1.4 & \text { II } & \\ -\mathrm{D} & - & & & & & \text { III } & \\ -\mathrm{E} & - & & & & & \text { IV } & \text { On 417D-B trend } \\ -\mathrm{F} & 417 \mathrm{D}-\mathrm{E} & 4.4 & 2.0 & 0.5 & 1.9 & \text { IV } & \begin{array}{c}\text { On 417D-B trend } \\ \text { V }\end{array} \\ \text {-G } & - & & & & & \text { V } & \begin{array}{l}\text { On 418A-B trend } \\ \text {-H }\end{array} \\ - & - & & & & & \text { VI } & \text { On 417D-B trend }\end{array}$

Hole 418A-

\begin{tabular}{|c|c|c|c|c|c|c|}
\hline $\begin{array}{l}-A \\
-B\end{array}$ & & & & & $\left.\begin{array}{l}\text { I } \\
\text { I }\end{array}\right\}$ & $\begin{array}{l}\text { Differences may be due to minor alteration } \\
\text { in several } 418 \mathrm{~A} \cdot \mathrm{A} \text { samples }\end{array}$ \\
\hline$-\mathrm{C}$ & & & & & II) & \\
\hline $\begin{array}{l}-\mathrm{D} \\
-\mathrm{E}\end{array}$ & & & & & III & $\begin{array}{l}\text { May reflect fractionation at higher pressures } \\
\text { Augite required, but not observed }\end{array}$ \\
\hline $418 \mathrm{~A}-\mathrm{G}$ & 12.1 & 6.1 & 0.5 & 5.5 & V & \\
\hline - & & & & & V & \\
\hline $418 \mathrm{~A}-\mathrm{G}$ & 15.0 & 7.0 & 0.8 & 7.2 & V & \\
\hline- & & & & & $\mathrm{V}$ & Equals $418 \mathrm{~A}-\mathrm{G}$ \\
\hline $418 \mathrm{~A}-\mathrm{G}$ & 11.9 & 6.2 & 1.3 & 4.4 & V & \\
\hline $418 \mathrm{~A}-\mathrm{G}$ & 4.8 & 2.3 & 0.6 & 1.9 & V & \\
\hline $418 \mathrm{~A}-\mathrm{B}$ & 14.8 & 8.8 & 1.7 & 4.3 & I & Dike \\
\hline$-\mathrm{M}$ & & & & & VI & Similar to $418 \mathrm{~A}-\mathrm{C}, \mathrm{D}, \mathrm{E}$ \\
\hline$-\mathrm{N}$ & & & & & VII & Similar to $418 \mathrm{~A}-\mathrm{A}, \mathrm{B}$ \\
\hline
\end{tabular}

Hole 418B-

$-\mathrm{O}$

I Equals $418 \mathrm{~A}-\mathrm{A}, \mathrm{B}$

\footnotetext{
${ }^{a}$ No correlations are implied between the magma batches in Holes 417D and 418A.
} 
TABLE 5

Glass Inclusions in Plagioclase Holes 417D and 418A

\begin{tabular}{|c|c|c|c|c|c|c|c|c|c|}
\hline Chemical Type & 417D-B & 417D-B & 417D-C & 417D-C & 417D-C & 417D-C & 417D-C & 417D-H & 417D-H \\
\hline $\begin{array}{c}\text { Sample } \\
\text { (Interval in } \mathrm{cm} \text { ) }\end{array}$ & $27-4,131$ & $27-4,131$ & $37-2,38$ & $37-2,38$ & $37-2,38$ & $39-4,75$ & $39-4,75$ & $62-2,15$ & $62-2,15$ \\
\hline Symbol & A & B & $\mathrm{C}$ & D & $\mathrm{E}$ & $\mathrm{F}$ & G & $\mathrm{H}$ & I \\
\hline $\mathrm{SiO}_{2}$ & 51.83 & 51.43 & 51.60 & 51.16 & 51.45 & 51.22 & 50.93 & 51.98 & 52.28 \\
\hline $\mathrm{Al}_{2} \mathrm{O}_{3}$ & 14.59 & 14.51 & 14.31 & 14.39 & 14.57 & 13.91 & 14.31 & 14.12 & 14.16 \\
\hline $\mathrm{FeOT}$ & 9.02 & 9.73 & 10.30 & 10.35 & 10.35 & 10.20 & 10.68 & 8.82 & 9.06 \\
\hline $\mathrm{MgO}$ & 8.94 & 9.49 & 8.55 & 8.62 & 8.17 & 9.54 & 9.17 & 10.82 & 10.61 \\
\hline $\mathrm{CaO}$ & 12.43 & 12.31 & 12.26 & 12.28 & 11.62 & 12.77 & 12.2 & 12.26 & 12.26 \\
\hline $\mathrm{Na}_{2} \mathrm{O}$ & 2.05 & 2.02 & 2.20 & 2.14 & 2.29 & 1.85 & 2.0 & 1.78 & 1.83 \\
\hline $\mathrm{K}_{2} \mathrm{O}$ & 0.06 & 0.05 & 0.08 & 0.06 & 0.09 & 0.06 & 0.06 & 0.06 & 0.02 \\
\hline $\mathrm{TiO}_{2}$ & 0.74 & 0.36 & 1.02 & 1.06 & 1.17 & 0.36 & 0.38 & 0.63 & 0.73 \\
\hline $\mathrm{P}_{2} \mathrm{O}_{5}$ & n.a. ${ }^{a}$ & 0.05 & 0.09 & n.a. & n.a. & 0.05 & n.a. & 0.08 & 0.10 \\
\hline $\mathrm{Cr}_{2} \mathrm{O}_{3}$ & 0.07 & n.a. & n.a. & 0.08 & 0.05 & n.a. & 0.07 & 0.10 & 0.11 \\
\hline Total & 99.73 & 99.95 & 100.41 & 100.14 & 99.76 & 99.96 & 99.80 & 100.57 & 101.04 \\
\hline
\end{tabular}

the Site $417 / 418$ compositions may reflect a fundamental difference in asthenospheric flow patterns in Cretaceous time.

\section{SUMMARY}

Fresh basaltic glasses are commonly found in very old oceanic crust. In DSDP Holes 417D and 418A analysis of 190 glassy selvages of pillows, massive flows, one hyaloclastite, and one dike have been used to determine the chemical variation of the basaltic liquids which produced the volcanic portion of this oceanic crust. These analyses are ideal in this respect because the glasses should not be influenced by redistribution of phenocryst phases and are unaffected by the alteration which affects the whole-rock analyses in many, if not all cases. These data clearly show that the Hole 417D and 418A basalts are similar to basalts produced at the modern Mid-Atlantic Ridge, though they seem to be more similar to basalts near $37^{\circ} \mathrm{N}$ than those at $22^{\circ} \mathrm{N}$ where they would have been generated.

The chemical stratigraphy in each hole is quite complex with more and less fractionated flows randomly interlayered. In some cases, low-pressure fractional crystallization can account for observed differences between two adjacent chemical units; in others, the units can only be related if fractionation of augite is included (even though not present in either unit); in still other cases, no fractionation model can explain observed differences. It therefore seems likely that, in spite of the very coherent trend in the glass compositions, multiple parental liquids are required to generate the Hole 417D and 418A basalts. These parental liquids must have been quite similar to generate the very uniform fractionation trends found for all the magma batches.

A preliminary look at glass inclusions suggests that even the most primitive basalts in Holes 417D and 418A have undergone extensive gabbroic fractionation. These inclusions are basaltic but have very low concentrations of $\mathrm{K}_{2} \mathrm{O}$, $\mathrm{TiO}_{2}$, and $\mathrm{P}_{2} \mathrm{O}_{5}$.

\section{ACKNOWLEDGMENTS}

We both thank the Smithsonian Institution for fellowship support, use of facilities, and invaluable help of numerous staff members, especially Tim O'Hearn and Richard Johnson. Byerly thanks the Deep Sea Drilling Project for support to participate on Leg 52. Sinton thanks the Deep Sea Drilling Project for support to participate on Leg 51. Hubert Staudigel sampled for us on Leg 53. This paper benefited from careful reviews by Bill Bryan and Ed Mathez.

\section{REFERENCES}

Anderson, R.N., McKenzie, D., and Sclater, J.G., 1973. Gravity, bathymetry and convection in the earth, Earth Planet. Sci. Lett., v. 18 , p. $391-407$.

Bryan, W.B. and Moore, J.G., 1977. Compositional variation of young basalts in the Mid-Atlantic Ridge rift valley near $36^{\circ} 49^{\prime}$ N, Geol. Soc. Am. Bull, v. 88, p. 556-570.

Byerly, G.R. and Wright, T.L., 1978. Origin of major-element chemical trends in DSDP Leg 37 basalts, Mid-Atlantic Ridge, $J$. Volcanology Geotherm. Res., v. 3, p. 229-279.

Byerly, G.R., Melson, W.G., Nelen, J., and Jarosewich, E., 1977. Abyssal basaltic glasses as indicators of magma compositions, Smithsonian Contrib. Earth Sci., no. 19, p. 22-30.

Dungan, M.A., Rhodes, J.M., Long, P.E., and Blanchard, D.P., 1977. Magma mixing at mid-ocean ridges: evidence from DSDP Legs 45 and 46, Geol. Soc. Am. Abstract with Programs, v. 9, p. 958-959.

Frey, F.A., Bryan, W.B., and Thompson, G., 1974. Atlantic Ocean floor: geochemistry and petrology of basalts from Legs 2 and 3 of the Deep-Sea Drilling Project, J. Geophys. Res., v. 79, p. $5507-5527$.

Hall, J.M. and Ryall, P.J.C., 1977. Paleomagnetism of basement rocks, Leg 37. In Aumento, F., Melson, W.G., et al., Initial Reports of the Deep Sea Drilling Project, v. 37: Washington (U.S. Government Printing Office), p. 425-448.

Jarosewich, E., Parkes, A.S., and Wiggins, L.B., in press. Microprobe analyses of four natural glasses and one mineral: An interlaboratory study of precision and accuracy, Smithsonian Contrib. Earth Sci.

Lofgren, G., 1974. An experimental study of plagioclase crystal morphology: isothermal crystallization, Am. J. Sci., v. 274, p. 243-273.

Melson, W.G., 1973. Basaltic glasses from the DSDP, chemical characteristics, compositions of alteration products, and fission track "ages," Am. Geophys. Union Trans., v. 54, p. 1011-1014. 
TABLE 5 - Continued

\begin{tabular}{lrrrrrrrrr}
\hline $\begin{array}{c}\text { Chemical Type } \\
\text { Sample }\end{array}$ & $417 \mathrm{D}-\mathrm{H}$ & $417 \mathrm{D}-\mathrm{H}$ & $417 \mathrm{D}-\mathrm{H}$ & $418 \mathrm{~A}-\mathrm{C}$ & $418 \mathrm{~A}-\mathrm{C}$ & $418 \mathrm{~A}-\mathrm{C}$ & $418 \mathrm{~A}-\mathrm{D}$ & $418 \mathrm{~A}-\mathrm{D}$ & $418 \mathrm{~A}-\mathrm{D}$ \\
$\begin{array}{c}\text { (Interval in cm) } \\
\text { Symbol }\end{array}$ & $62-2,15$ & $66-6,30$ & $66-6,30$ & $42-3,17$ & $42-3,17$ & $42-3,17$ & $44-3,73$ & $44-3,73$ & $44-3,73$ \\
\hline $\mathrm{SiO}_{2}$ & 51.22 & 51.34 & 52.00 & 50.69 & 50.64 & 51.27 & 50.68 & 51.04 & 51.65 \\
$\mathrm{Al}_{2} \mathrm{O}_{3}$ & 14.05 & 14.12 & 14.24 & 15.07 & 15.33 & 15.06 & 15.34 & 15.38 & 15.08 \\
$\mathrm{FeOT}_{\mathrm{MgO}}$ & 9.16 & 10.33 & 9.59 & 9.25 & 9.13 & 8.98 & 8.39 & 8.28 & 8.55 \\
$\mathrm{CaO}$ & 10.07 & 7.51 & 8.87 & 9.32 & 9.86 & 9.41 & 9.20 & 8.96 & 9.28 \\
$\mathrm{Na}_{2} \mathrm{O}$ & 12.26 & 11.56 & 12.84 & 13.29 & 13.04 & 13.29 & 12.35 & 12.50 & 12.68 \\
$\mathrm{~K}_{2} \mathrm{O}$ & 1.89 & 2.30 & 1.97 & 1.89 & 2.04 & 1.86 & 2.21 & 2.18 & 2.15 \\
$\mathrm{TiO}_{2}$ & 0.04 & 0.10 & 0.05 & 0.05 & 0.03 & 0.05 & 0.05 & 0.04 & 0.04 \\
$\mathrm{P}_{2} \mathrm{O}_{5}$ & 0.66 & 1.17 & 0.67 & 0.50 & 0.47 & 0.49 & 0.78 & 0.72 & 0.82 \\
$\mathrm{Cr}_{2} \mathrm{O}_{3}$ & 0.06 & 0.12 & n.a. & 0.05 & n.a. & 0.08 & 0.09 & 0.06 & 0.06 \\
$\mathrm{Total}$ & 0.10 & n.a. & 0.03 & n.a. & 0.08 & n.a. & 0.11 & n.a. & n.a. \\
\hline
\end{tabular}

$a_{\text {n.a. }}=$ not analyzed.

, 1979. Chemical stratigraphy of Leg 45 basalts: electron probe analyses of glasses. In Melson, W.G., Rabinowitz, P.D., et al., Initial Reports of the Deep Sea Drilling Project, v. 45: Washington (U.S. Government Printing Office), p. 507-512.

Melson, W.G., Vallier, T.L., Wright, T.L., Byerly, G., and Nelen, J., 1976. Chemical diversity of abyssal volcanic glass erupted along the Pacific, Atlantic, and Indian Ocean sea-floor spreading centers. In Sutton, G., Manghnani, M.H., and Moberly, R. (Eds.), The geophysics of the Pacific Ocean basin and its margin: Am. Geophys. Union Mono. 20, p. 351-367.

Roedder, E. and Weiblen, P.W., 1971. Petrology of silicate melt in inclusions, Apollo rocks, Geochim. Cosmochim. Acta, v. 1, p. 801-837.
Schilling, J.G., Kingsley, R., and Bergeron, M., 1977. Rare earth abundances in DSDP Sites 332, 334, and 335, and inferences on the Azores mantle blob with time. In Aumento, F., Melson, W.G., et al., Initial Reports of the Deep Sea Drilling Project, v. 37: Washington (U.S. Government Printing Office), p. 591-598.

Watson, E.B., 1976. Glass inclusions as samples of early magmatic liquids: determinative methods and applications to a South Atlantic basalt, J. Volcanology Geotherm. Res., v. 1, p. 73-84.

Wright, T.L. and Helz, R.T., 1976. Use of mass-balance equations to evaluate models of magma genesis, Geol. Soc. Am. Abstract with Programs, v. 8, p. 1176. 